\title{
Results of PMIP2 coupled simulations of the Mid-Holocene and Last Glacial Maximum - Part 2: feedbacks with emphasis on the location of the ITCZ and mid- and high latitudes heat budget
}

\author{
P. Braconnot ${ }^{1}$, B. Otto-Bliesner ${ }^{2}$, S. Harrison ${ }^{3}$, S. Joussaume ${ }^{1}$, J.-Y. Peterchmitt ${ }^{1}$, A. Abe-Ouchi ${ }^{4}$, M. Crucifix ${ }^{5,6}$, \\ E. Driesschaert ${ }^{6}$, Th. Fichefet ${ }^{6}$, C. D. Hewitt ${ }^{5}$, M. Kageyama ${ }^{1}$, A. Kitoh ${ }^{7}$, M.-F. Loutre ${ }^{6}$, O. Marti ${ }^{1}$, U. Merkel ${ }^{8}$, \\ G. Ramstein ${ }^{1}$, P. Valdes ${ }^{3}$, L. Weber ${ }^{9}$, Y. Yu ${ }^{10}$, and Y. Zhao ${ }^{3}$ \\ ${ }^{1}$ Laboratoire des Sciences du Climat et de l'Environnement, Unité mixte CEA-CNRS-UVSQ, Orme des Merisiers, bât. 712, \\ 91191 Gif-sur-Yvette Cedex, France \\ ${ }^{2}$ National Center for Atmospheric Research, 1850 Table Mesa Drive, Boulder, Colorado, USA \\ ${ }^{3}$ School of Geographical Sciences, University of Bristol, Bristol, BS8 1SS, UK \\ ${ }^{4}$ Center for Climate System Research, The University of Tokyo, Japan 277-8568 and FRCGC/JAMSTEC, Yokohama \\ 236-0001, Japan \\ ${ }^{5}$ Met Office Hadley Centre, Fitzroy Road, Exeter EX1 3PB, UK \\ ${ }^{6}$ Université Catholique de Louvain, Institut d'Astronomie et de Géophysique Georges Lemaître, B-1348 Louvain-la-Neuve, \\ Belgium \\ ${ }^{7}$ Meteorological Research Institute, Tsukuba, Ibaraki 305-0052, Japan \\ ${ }^{8}$ Universität Bremen, FB5 Geosciences, Geosystem modelling, P.O. Box 330 440, 28334 Bremen, Germany \\ ${ }^{9}$ Royal Netherlands Meteorological Institute, P.O. Box 201, 3730 AE De Bilt, The Netherlands \\ ${ }^{10}$ LASG, Institute of Atmospheric Physics, Chinese Academy of Sciences, P.O. Box 9804, Beijing 100029, P. R. China
}

Received: 6 November 2006 - Published in Clim. Past Discuss.: 13 December 2006

Revised: 16 April 2007 - Accepted: 14 May 2007 - Published: 4 June 2007

\begin{abstract}
A set of coupled ocean-atmosphere(-vegetation) simulations using state of the art climate models is now available for the Last Glacial Maximum (LGM) and the MidHolocene (MH) through the second phase of the Paleoclimate Modeling Intercomparison Project (PMIP2). Here we quantify the latitudinal shift of the location of the Intertropical Convergence Zone (ITCZ) in the tropical regions during boreal summer and the change in precipitation in the northern part of the ITCZ. For both periods the shift is more pronounced over the continents and East Asia. The maritime continent is the region where the largest spread is found between models. We also clearly establish that the larger the increase in the meridional temperature gradient in the tropical Atlantic during summer at the $\mathrm{MH}$, the larger the change in precipitation over West Africa. The vegetation feedback is however not as large as found in previous studies, probably due to model differences in the control simulation. Finally, we show that the feedback from snow and sea-ice at mid and high latitudes contributes for half of the cooling in the Northern Hemisphere for the LGM, with the remaining being achieved by the reduced $\mathrm{CO}_{2}$ and water vapour in the
\end{abstract}

Correspondence to: P. Braconnot

(pascale.braconnot@cea.fr) atmosphere. For the MH the snow and albedo feedbacks strengthen the spring cooling and enhance the boreal summer warming, whereas water vapour reinforces the late summer warming. These feedbacks are modest in the Southern Hemisphere. For the LGM most of the surface cooling is due to $\mathrm{CO}_{2}$ and water vapour.

\section{Introduction}

Several coupled ocean atmosphere (OA) and oceanatmosphere-vegetation simulations (OAV) of the Last Glacial Maximum (LGM, 21000 years ago) and the Mid-Holocene (MH, 6000 years ago) are available as part of the second phase of the Paleoclimate Modelling Intercomparison Project (PMIP2, Harrison et al., 2002). In a first part we have presented an overview of the results and have compared them to the PMIP1 simulations, performed with atmosphere alone models forced with prescribed sea surface temperatures (SST) or coupled to a slab ocean model (see Braconnot et al., 2007). Both paleoclimatic periods considered are characterised by large changes in the hydrological cycle in the tropical regions. Several feedbacks from ocean, vegetation, snow and ice occur in the climate system and amplify

Published by Copernicus Publications on behalf of the European Geosciences Union. 
or damp the initial forcing from ice-sheet, insolation or trace gases. In this second part, the focus is thus on these feedbacks, their link with the location of the Intertropical Convergence Zone (ITCZ) in the tropical regions, and their link with the changes in the radiative heat budget in the mid- and high latitudes.

The objectives are first to use the set of PMIP1 and PMIP2 simulations to investigate how the location of the ITCZ changes for LGM and Mid-Holocene and to analyse if the ocean feedback has an impact on this change. Indeed, both periods are characterised by major changes in the hydrological cycle in the tropics, and changes in precipitation inferred from proxy indicators tend to be often attributed to shifts in the mean position of the ITCZ (e.g. Haug et al., 2001). However, previous analyses of LGM changes in precipitation from PMIP1 simulations over Africa suggested depleted rainfall in the ITCZ, with nearly no shift in ITCZ location (Braconnot et al., 2000a). On the other hand, results for 6ka suggested that the northern limit of precipitation shifted indeed to the north over the Sahel region, but that for most models the core of the ITCZ remained in a position similar to today (Joussaume et al., 1999; Braconnot et al., 2000a).

The location of the ITCZ and the change in precipitation are affected by several feedbacks, including the ocean and vegetation feedbacks which were investigated during PMIP1, and with previous versions of OA and OAV models by individual groups (see Braconnot et al., 2004; or Cane et al., 2006). These studies lead to the conclusion that both ocean and vegetation feedbacks are needed to represent the moist MH conditions reported from data in the Sahel region (Braconnot et al., 1999; Braconnot et al., 2004). The new PMIP2 simulations with interactive vegetation only slightly increase rainfall compared to OA simulations (see Fig. 9 in Part 1). Vegetation feedback thus seems less important than it was stated from previous OAV experiments (Braconnot et al., 1999) or from coupled atmosphere-vegetation experiments (e.g. Claussen and Gayler, 1997; Texier et al., 1997). In contrast, the ocean feedback seems in better agreement with previous studies. We discuss these aspects mainly focussing on the African monsoon during the $\mathrm{MH}$. We also consider that these feedbacks may be affected by model biases that we infer from the pre-industrial simulations.

At mid and high latitudes, changes in the snow and seaice covers have direct effects on surface albedo, and thereby on the radiative heat budget and temperature. For example, the large ice sheets present in the Northern Hemisphere (NH) during LGM contribute to about -3.3 to $-2.0 \mathrm{~W} / \mathrm{m}^{2}$ of the radiative cooling at this period (Taylor et al., 2000, 2007). The resulting cooling, in turn, increases the snow and ice cover which further cools down the system. Feedbacks from snow and sea-ice are also expected for the $\mathrm{MH}$ at the seasonal time scale. We investigate these feedbacks by analysing how changes in snow and sea-ice covers influence climate between $30^{\circ}$ and $90^{\circ}$ latitude in both hemispheres. The analyses first consider the changes in snow and ice for both time periods and then evaluate the impact of these changes on the top of the atmosphere heat budget.

We consider the PMIP2 coupled experiments described in Part 1 (see Tables 1 and 2), as well as PMIP1 simulations performed several years ago. Section 2 presents the changes in the location of the ITCZ and of precipitation in its northern edge. How feedbacks from ocean and vegetation affect the African monsoon for the MH is discussed in Sect. 3. Changes in snow and sea-ice and the impact these changes have on the radiative heat budget at the top of the atmosphere in mid-and high latitudes are analysed for the two past climatic periods in Sects. 4 and 5 respectively. The conclusion is provided in Sect. 6.

\section{Tropical regions and location of the ITCZ}

\subsection{Location of the ITCZ}

There is no robust criterion to define the northern limit of the ITCZ from precipitation. The reason is that the background level of precipitation varies a lot from model to model, and that some models produce spurious precipitation in arid regions (Braconnot et al., 2000a). Therefore we consider the core of the ITCZ in its northern part rather than the northern limit of the ITCZ. We refer to this as the location of the ITCZ in the following. For each longitude we computed the latitudinal location of the centre of gravity of precipitation for precipitation located to the north of the maximum precipitation (peak of the ITCZ). The mean location is therefore provided by :

$$
\operatorname{loc} \_\operatorname{ITCZ}(\text { lon })=\frac{\sum_{y=\operatorname{lat}(p r \max )}^{30^{\circ} \mathrm{N}} \operatorname{pr}(y) \operatorname{lat}(y)}{\sum_{y=\operatorname{lat}(p r \max )}^{30^{\circ} \mathrm{N}} \operatorname{pr}(y)},
$$

where lon stands for longitude, lat() for the latitude where precipitation is computed in the model, $p r$ for precipitation and $p r$ max for the maximum precipitation. We computed the location of the ITCZ for each model on its own model grid. Figures 1 and 2 give for each model the northern most position (loc_ITCZ(lon)) reached during JJAS for each longitude. Because of the different model resolutions in longitude, some models contribute for more points in this figure. In order to evaluate if the location of the ITCZ is properly represented by the models, we apply the same procedure to the CMAP climatology (Xie and Arkin, 1996) and include it (red line) on each of the graphs of Figs. 1 and 2, to provide both a reference for the control simulations and a fixed line to evaluate the shift of the ITCZ in LGM and MH simulations.

In order to better see the changes in the location of the ITCZ and in the amount of precipitation in the northern part of the ITCZ, we also plotted, for each of the models and each 
a) PMIP2 OA OAV CTRL

PMIP2 OA OAV LGM

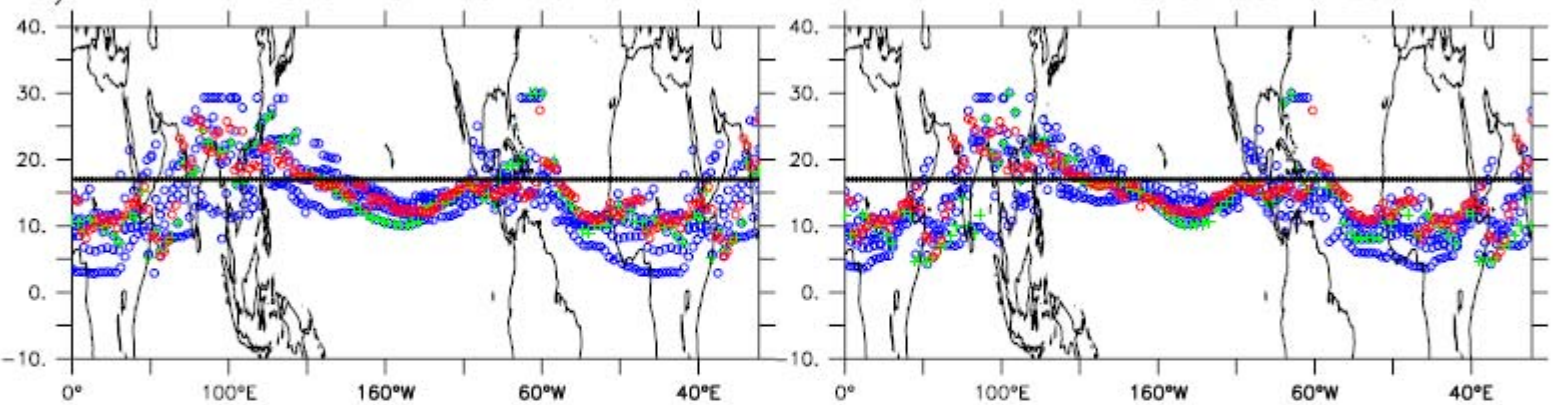

b) PMIP1 SSTf CTRL

PMIP1 SSTf LGM

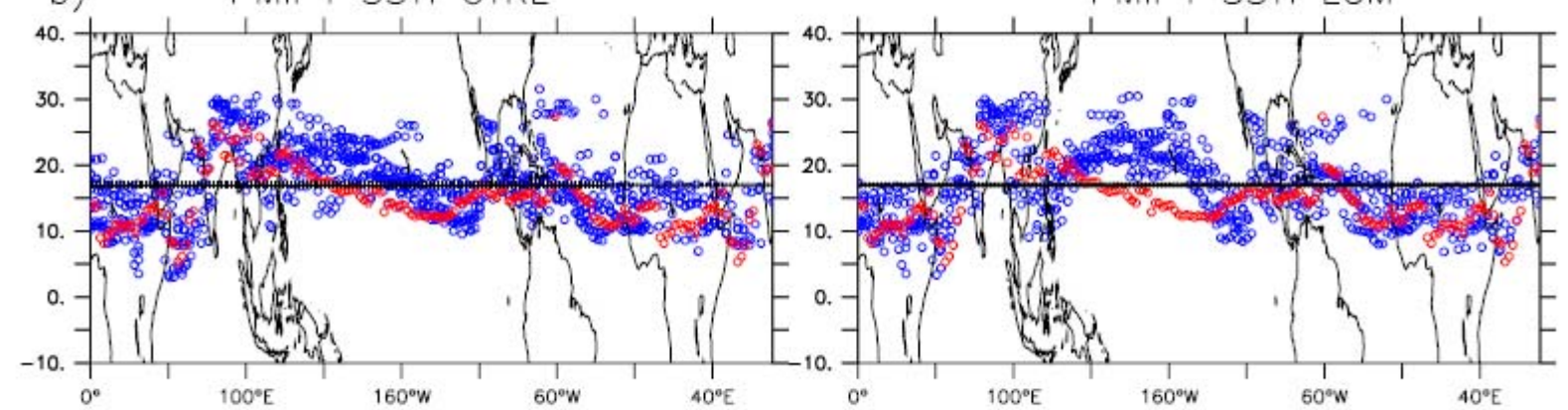

c) PMIP1 SSTC CTRL

PMIP1 SSTC LGM

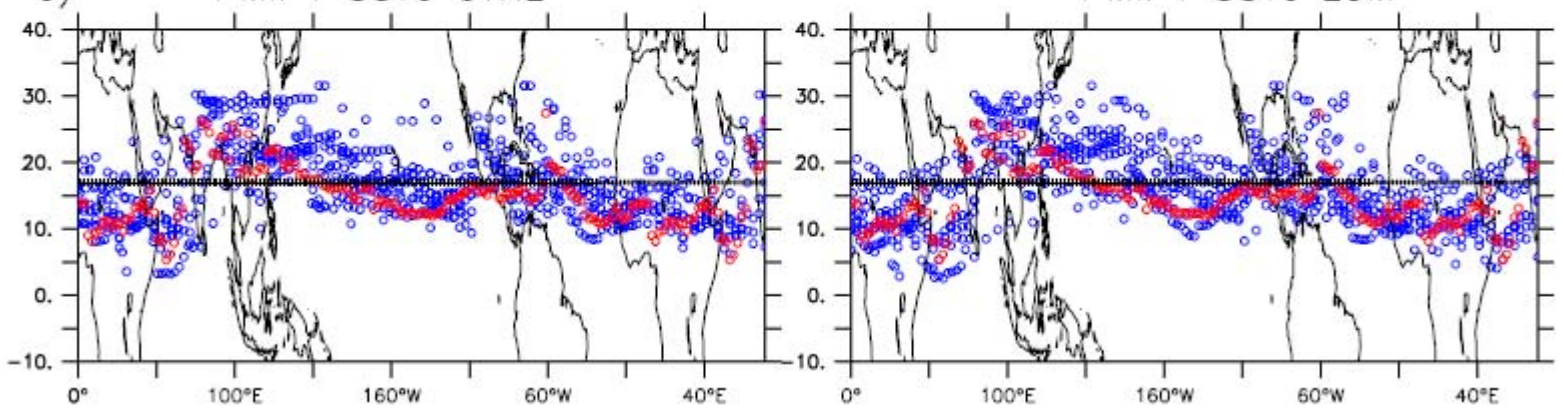

Fig. 1. Location of the ITCZ at the northern edge of its seasonal march (see text for the exact definition, and the criterion used to compute it) for pre-industrial (left) and LGM simulations (right), and (a) PMIP2 OA and OAV, (b) PMIP1 SSTf, and (c) PMIP1 SSTc simulations. Blue circles are the estimates from the different model results. Red circles are the reference from the CMAP climatology of precipitation. In addition the $17^{\circ} \mathrm{N}$ latitude is also drawn on all graphs to provide a visual reference. In (a), the green circles represent the results of the HadCM3M2 OAV simulations (see Table in Part 1).

of the past climates (pal), the magnitude of the shift in latitude of the ITCZ as a function of longitude in Fig. 3. This shift is simply defined as:

$\Delta \mathrm{lat}=\left(\operatorname{loc} \_ \text {ITCZ }(\text { lon })\right)_{\text {pal }}-(\text { loc_ITCZ (lon) })_{\text {CTRL }}$

Figure 3 also includes for each model the change in precipitation averaged over the northern edge of the ITCZ as a function of longitude. It is defined as:

$\Delta p r($ lon $)=\left(\frac{\sum_{y=\operatorname{lat}(p r \max )}^{30^{\circ} \mathrm{N}} p r(y) d y}{\sum_{y=\operatorname{lat}(p r \max )}^{30^{\circ} \mathrm{N}} d y}\right)_{\mathrm{pal}}-\left(\frac{\sum_{y=\operatorname{lat}(p r \max )}^{30^{\circ} \mathrm{N}} p r(y) d y}{\sum_{y=\operatorname{lat}(p r \max )}^{30^{\circ} \mathrm{N}} d y}\right)_{\mathrm{CTRL}}$ where $d y$ represents the latitudinal length (expressed in $\mathrm{m}$ ) of each model grid box.

\subsection{ITCZ in the pre-industrial simulations}

Figures 1 and 2 present the results for the control simulations used as references for the LGM and MH simulations respectively. They correspond to different subsets of models discussed in Part 1 (Table 1). The comparison of PMIP2 OA results of Fig. 1a for 0ka with observations shows that most OA models capture the location of the ITCZ quite well. The major deficiencies occur over Africa where the ITCZ is located too far south in two simulations and over the Indian Ocean. In this region, one of the models favours convection 

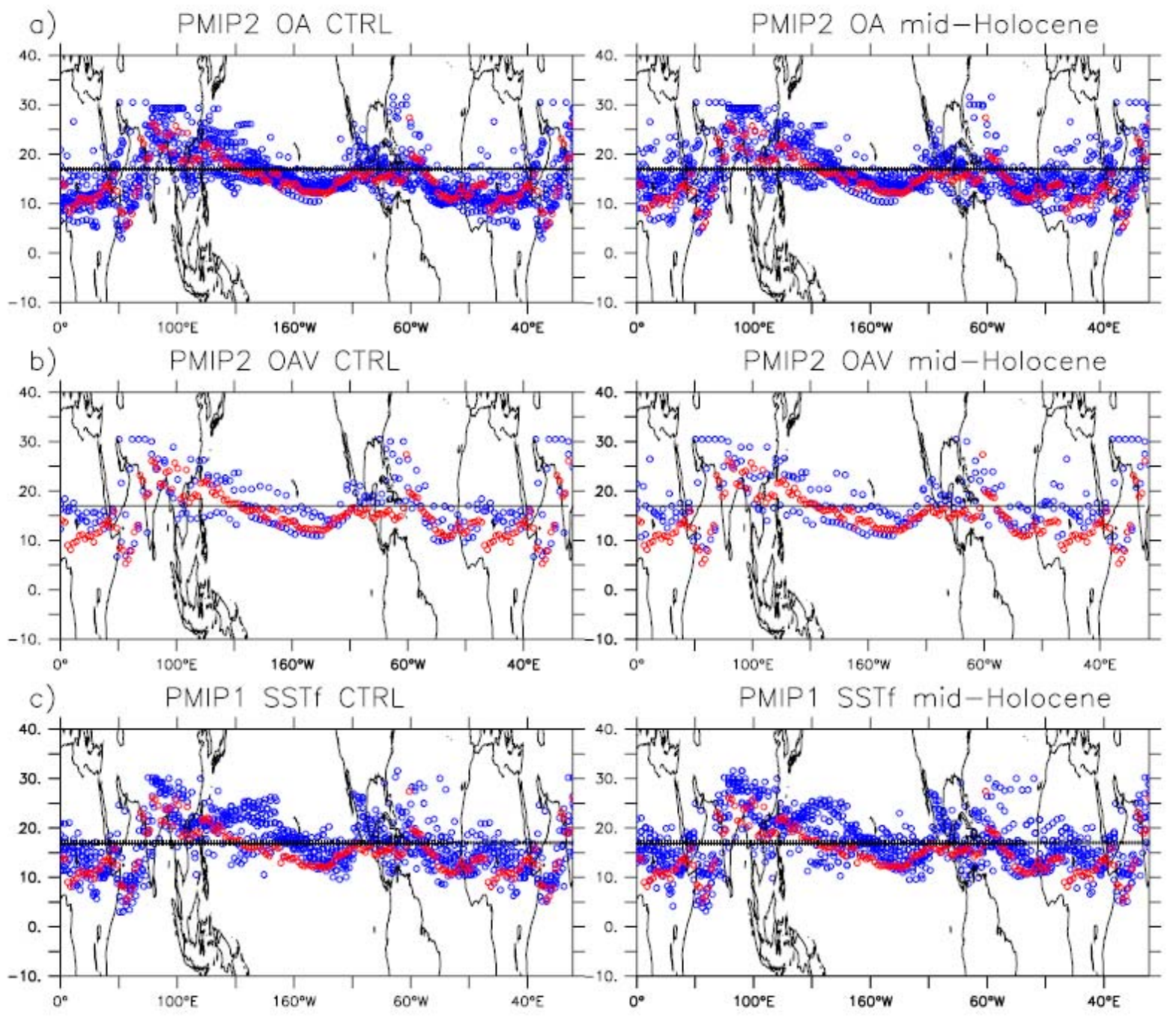

Fig. 2. Same as Fig. 1, but for the MH, and (a) PMIP2 OA, (b) PMIP2 OAV, and (c) PMIP1 SSTf simulations.

over the ocean at the expense of the continent. Interestingly results of this subset of coupled models are in better agreement with the climatology than PMIP1 SSTf or SSTc simulations performed several years ago (Fig. 1b and c, left panels). In these earlier simulations, the location of the ITCZ is not well reproduced over the ocean and model to model differences can reach up to $20^{\circ}$ in latitude. The scatter is even larger over the ocean for slab ocean models. This is particularly true over the West Pacific. Several models locate the ITCZ too far north over West Africa, mainly in the PMIP1 SSTf experiments (Joussaume et al., 1999). This comparison shows that the atmospheric component of the models has been improved during the last decade.

When considering the whole set of simulations, Fig. 2 reveals that some of the additional models included in this set (e.g. ECBilt-CLIO-VECODE, FOAM, and UBRIS_HadCM3M2) have a tendency to locate the modern ITCZ too far north over West Africa and the Panama isth- mus. This feature appears also in the results of the three corresponding $\mathrm{OAV}$ pre-industrial simulations.

\subsection{Simulated changes for Last Glacial Maximum}

At first look it is difficult to distinguish notable changes in the location of the ITCZ from PMIP2 OA and OAV LGM simulations (Fig. 1a, right panel). The reason for this is that the scatter between model results for the preindustrial period $(0 \mathrm{ka})$ is larger than the ITCZ change simulated for the LGM (Fig. 1a, left panel). However, the change in the position of the ITCZ (Fig. 3c) shows that some of the models simulate a southward shift of the ITCZ over the continents and the Indian Ocean. The OAV simulation (HadCM3M2) is amongst the simulations for which the shift is the largest. Note that one of the models (crosses in Fig. 3c) is more sensitive than the others over Africa with a shift of about 5 to 8 degrees in latitude compared to $0 \mathrm{ka}$. The southward shift 

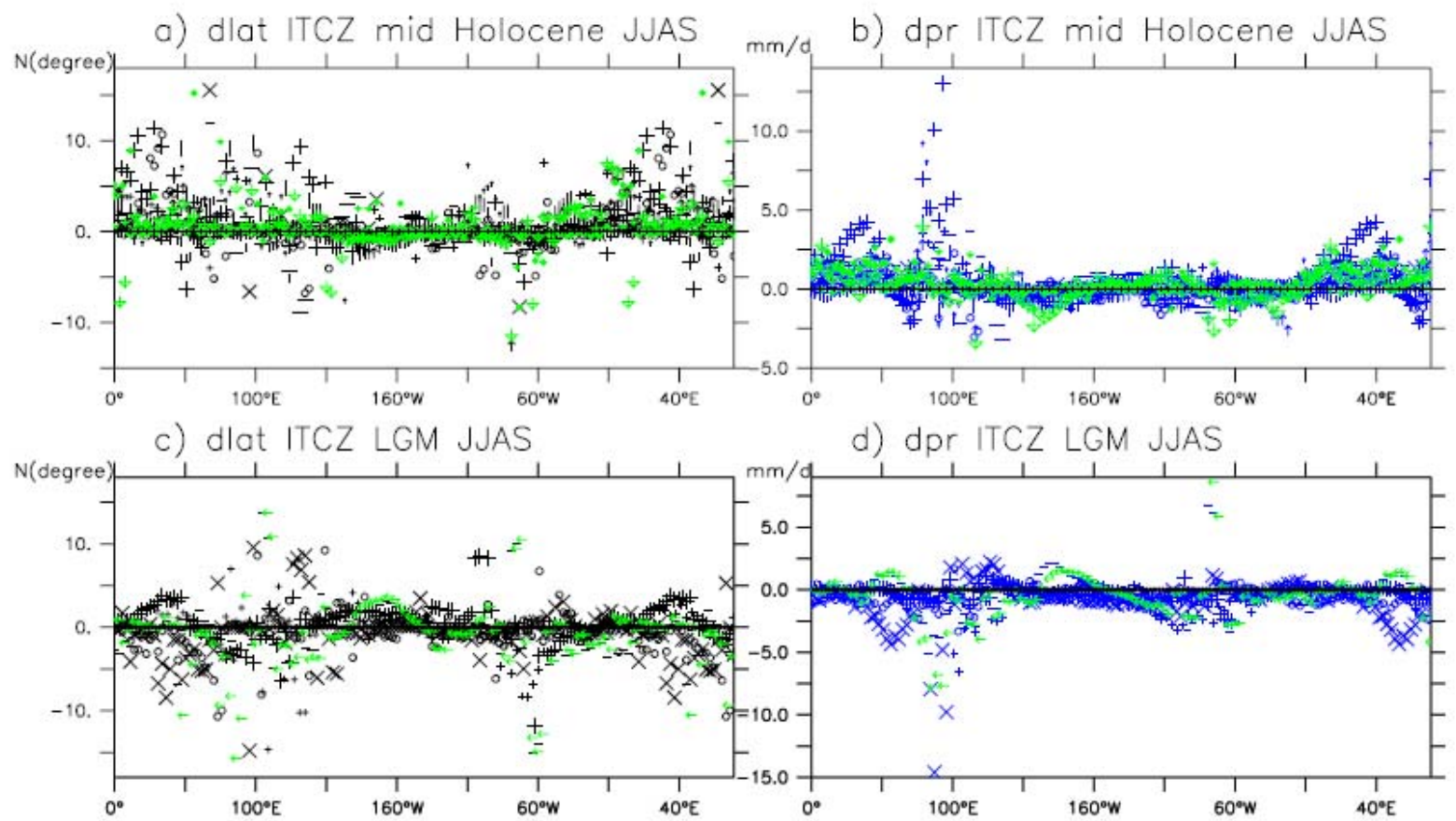

Fig. 3. Change in the northern most location of the ITCZ (degrees of latitude) as simulated by PMIP2 OA simulations for (a) the MH and (c) the LGM, and change in the mean precipitation ( $\mathrm{mm} / \mathrm{d}$ ) in the northern part of the ITCZ for (b) the MH, and (d) the LGM (see text for detailed calculation). The zero line is plotted in green as a reference. The different symbols on the figure stand for the different models.

Table 1. PMIP2 OA and OAV model characteristics and references. The last two columns indicate which time slices were performed for each model. The crosses stand for OA simulations and the circles for OAV simulations.

\begin{tabular}{|c|c|c|c|c|c|c|}
\hline $\begin{array}{ll}\text { Model name as } \\
\text { specified in PMIP2 } \\
\text { database }\end{array}$ & $\begin{array}{l}\text { Resolution } \\
\text { Atm Long } \times \text { lat } \\
\text { (levels) }\end{array}$ & $\begin{array}{l}\text { Ocean Long } \times \text { lat } \\
\text { (levels) }\end{array}$ & $\begin{array}{l}\text { Flux } \\
\text { Adjustment }\end{array}$ & Reference for model & $6 \mathrm{ka}$ & $21 \mathrm{ka}$ \\
\hline CCSM3 & T42 (26) & $1^{\circ} \times 1^{\circ}(40)$ & None & Otto-Bliesner (2006) & $\mathrm{x}$ & $\mathrm{x}$ \\
\hline ECBilt-Clio & $\mathrm{T} 21(3)$ & $3 \times 3(20)$ & Basin-mean & Vries and Weber (2005) & & $\mathrm{x}$ \\
\hline $\begin{array}{l}\text { ECBilt-CLIO- } \\
\text { VECODE }\end{array}$ & $\mathrm{T} 21(3)$ & $3 \times 3(20)$ & & Renssen et al. (2005) & xo & \\
\hline ECHAM5-MPIOM1 & T31 (19) & $1.875^{\circ} \times 0.84^{\circ}(40)$ & None & $\begin{array}{l}\text { Roeckner et al. (2003), } \\
\text { Marsland et al. (2003), } \\
\text { Haak et al. (2003) }\end{array}$ & $\mathrm{x}$ & \\
\hline FGOALS-g1.0 & $2.8 \times 2.8(26)$ & $1^{\circ} \times 1^{\circ}(33)$ & None & $\begin{array}{l}\text { Yu et al. (2002), } \\
\text { Yu et al. (2004). }\end{array}$ & $\mathrm{x}$ & $\mathrm{x}$ \\
\hline FOAM & $\mathrm{R} 15$ & $2.8^{\circ} \times 1.4^{\circ}(16)$ & None & Jacob et al. (2001) & xo & \\
\hline HadCM3M2 & $3.75^{\circ} \times 2.5^{\circ}(19)$ & $1.25^{\circ} \times 1.25^{\circ}(20)$ & None & Gordon et al. (2000) & & xo \\
\hline UBRIS-HadCM3M2 & $3.75^{\circ} \times 2.5^{\circ}(19)$ & $1.25^{\circ} \times 1.25^{\circ}(20)$ & None & Gordon et al. (2000) & xo & \\
\hline IPSL-CM4-V1-MR & $3.75^{\circ} \times 2.5^{\circ}(19)$ & $2^{\circ} \times 0.5^{\circ}$ & None & Marti et al. (2005) & $\mathrm{x}$ & $\mathrm{x}$ \\
\hline MIROC3.2 & T42 (20) & $1.4^{\circ} \times 0.5^{\circ}(43)$ & None & $\begin{array}{l}\text { K-1 Model Developers } \\
\text { (K-1-Model-Developers, } \\
\text { 2004) }\end{array}$ & $\mathrm{x}$ & $\mathrm{x}$ \\
\hline MRI-CGCM2.3fa & T42 (30) & $2.5^{\circ} \times 0.5^{\circ}(23)$ & Yes & Yukimoto et al. (2006) & $\mathrm{x}$ & \\
\hline MRI-CGCM2.3nfa & $\mathrm{T} 42(30)$ & $2.5^{\circ} \times 0.5^{\circ}(23)$ & None & Yukimoto et al. (2006) & $\mathrm{x}$ & \\
\hline
\end{tabular}


is very consistent between models over South America. This is in agreement with the results of Leduc et al. (2007) who found from marine data that when the North Atlantic is cold the ITCZ shifts to the south on both side of the Panama Isthmus. Near $130^{\circ} \mathrm{E}$ most models produce a 8 to $10^{\circ}$ latitude shift to the south. However the model spread is large, since some of the simulations produce a northward shift (Fig. 3c). This is particularly well marked on the foothills of Himalaya (Figs. 3c and 1a). Across the Pacific Ocean the tendency is for a slight southward shift in the eastern part and northward shift in the western part. Interestingly, even though the LGM climate is characterised by a drying in regions under the influence of the ITCZ, the mean amount of precipitation simulated on the northern edge of the ITCZ is only slightly reduced for most longitudes (Fig. 3d). The largest reduction occurs over Africa $\left(20^{\circ} \mathrm{W}-40^{\circ} \mathrm{E}\right)$, Indian and Asian $\left(70^{\circ} \mathrm{E}-\right.$ $110^{\circ} \mathrm{E}$ ), where monsoon is less active, and South America $\left.60^{\circ} \mathrm{W}-80^{\circ} \mathrm{W}\right)$. Note a tendency for increased precipitation over Southeast Asia and the West Pacific.

In contrast, PMIP1 prescribed (SSTf) and computed (SSTc) sea surface temperature (SST) LGM simulations produce a larger northward migration of the ITCZ over the Pacific Ocean (Figs. 1b and c). For PMIP1 SSTf simulations this coincides with the warm pool of the CLIMAP SSTs over which evaporation is still active and precipitation is enhanced (see Part 1). Results of SSTc experiments lay in between PMIP2 OA and PMIP1 SSTf results (Fig. 1c). Systematic differences compared to PMIP2 OA simulations remain, such as the northward shift across the Pacific. The comparison of these different sets of simulations suggest that the differences in SSTs between simulated SSTs and CLIMAP SSTs has a large impact on the hydrological cycle in the tropical regions and strongly influences the mean position of the ITCZ, by reducing its latitudinal shift over the ocean when SST is computed.

\subsection{Simulated changes for Mid-Holocene}

Figures 2, 3a and $\mathrm{b}$ show the same diagnostics computed for the MH. A northward shift of the ITCZ is simulated by almost all models over Africa and in the Indian sector extending to $130^{\circ} \mathrm{E}$ (Fig. 3a). It reaches 3 to 10 degrees of latitude depending on the region. It is associated to an increase of the mean precipitation simulated over the northern edge of the ITCZ. On average this increase is 2 to $4 \mathrm{~mm} / \mathrm{d}$ over Africa and three of the models simulate an increase larger that $6 \mathrm{~mm} / \mathrm{d}$ over the Indian monsoon region (Fig. 3b). A southward shift of the ITCZ is also simulated over South America where precipitation decreases by 2 to $4 \mathrm{~mm} / \mathrm{d}$, following results reported by Dias et al. (2007) ${ }^{1}$. Interestingly, the ITCZ in this region reacts in a similar way to the very

\footnotetext{
${ }^{1}$ Silva Dias, P. L., Silva Dias, M. A. F., Braconnot, P., Turcq, B., and Jorgetti, T.: Evaluation of Model Simulation of $6 \mathrm{ka} \mathrm{BP}$ and Present Climate in Tropical South America, Clim. Dyn., submitted, 2007.
}

different LGM and MH forcings. The Indian sector is the region where the larger scatter is found between models. In this sector, the modern ITCZ oscillates during boreal summer between an oceanic and continental position (Gadgil and Sajani, 1998). Some of the models favour the ocean location at $6 \mathrm{ka}$. Note that there is no relationship between the change in the location of the ITCZ and the change in the amount of precipitation.

Comparison with PMIP1 simulations indicates that these broad features were already present in PMIP1 SSTf simulations, but that the northward shift was of smaller magnitude, at least over West Africa (Fig. 2b, right panel). This is consistent with previous comparisons of coupled OA simulations of the MH (Zhao et al., 2005), and with the comparison with data presented in Part 1. Large differences are found over the West Pacific between the LGM OA and SSTf simulations, but they mainly result from differences in the control simulations (Fig. 2, left panels).

\section{Discussion of some identified feedbacks for the Mid- Holocene}

\subsection{Ocean feedback}

Comparison of PMIP1 and PMIP2 simulations confirms that the ocean feedback strengthens the African monsoon (see Sect. 4.2 in Part 1). The SST responds with about one month delay to the insolation forcing. The colder than present Surface Ocean in spring in the tropical regions and in the southern hemisphere contributes to enhance the land-sea constrast and the inland advection of moist air over the continent (Kutzbach and Liu, 1997; Braconnot et al., 2000b). In addition, warmer than present SSTs develop to the north of $5^{\circ} \mathrm{N}$ in late summer, while SSTs remain colder or close to what they are today to the south of $5^{\circ} \mathrm{N}$. Zhao et al. (2005) examined how this late summer SST dipole across $5^{\circ} \mathrm{N}$ in the tropical Atlantic increases the length of the African monsoon, and how this dipole structure is created and maintained. They showed that it involves wind evaporation feedback and increased Ekman transport at the seasonal time scale. We further confirm the role of this increased meridional SST gradient in the tropical Atlantic from the PMIP2 results. For this, we consider the canonical correlation (CCA) between tropical Atlantic SST and Sahel precipitation for the mean seasonal cycle of the difference between 6ka and 0ka following the method developed by Zhao et al. (2007) in their analysis of interannual variability. Here, instead of considering for one model each year as an individual representation of anomalies to the mean seasonal cycle, we consider each model result as an independent realisation of the mean seasonal cycle. Our analyses therefore reflect differences in the way the models represent the mean seasonal cycle. The second canonical patterns are representative of summer conditions (maps in Fig. 4). The SST pattern is characterised 
(a)

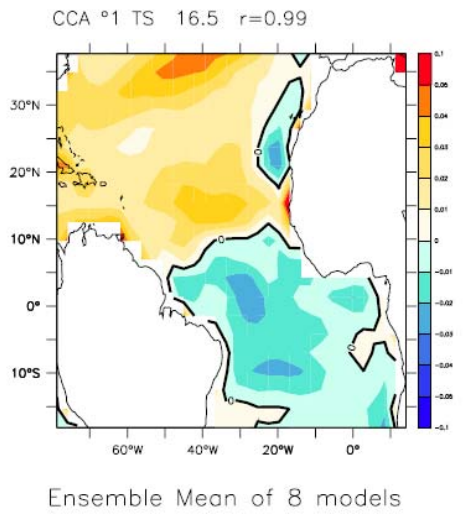

(b)

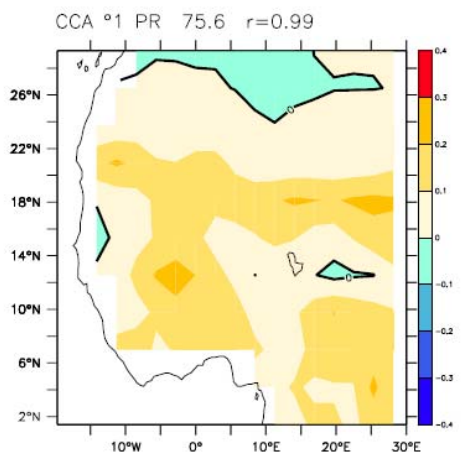

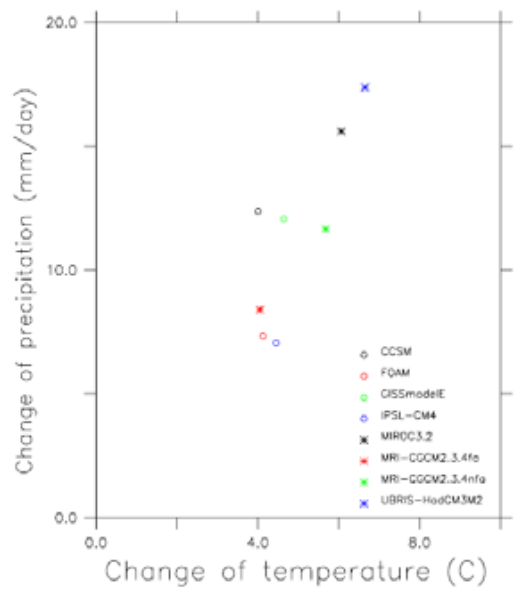

Fig. 4. Sahel precipitation amplification by the Atlantic dipole for the MH(arbitrary units), (a) 2nd CCA patterns of SST change in the Atlantic Ocean and of precipitation change over Africa, (b) relationship between the projection of the different model results on this pattern during summer (each dot represent a model), see text for details.

by warmer SST to the north of $5^{\circ} \mathrm{N}$ and colder SST to the south of $5^{\circ} \mathrm{N}$. The corresponding pattern of precipitation over land highlights the increased $\mathrm{MH}$ precipitation to the north of $10^{\circ} \mathrm{N}$. For each model, curves representing the time evolution of these structures are obtained by projecting the seasonal cycle of SST and precipitation on these spatial patterns. We extracted from each time series the value for JJAS for SST and precipitation respectively and computed the JJAS average. So for each model we end up with 2 numbers. The first one indicates the strength of the JJAS SST pattern (Fig. 4) for this model and the second indicates the strength of the corresponding precipitation pattern. The relationship between the values of SST and precipitation obtained for each model clearly exhibits a linear trend, with higher values for models with larger increase in SST gradient and larger change in precipitation over land (Fig. 4b). This result confirms the role of the ocean in triggering the monsoon trough and the advection of moist air from the ocean to the continent (Zhao et al., 2005).

This mechanism is only active in the Atlantic Ocean. In the Indian Ocean and over the warm pool region of the Pacific the change in SST reduces the amplification of the Indian monsoon (see Part 1). In the Indian sector, low level winds tend to converge over the warmer western tropical North Pacific, so that less moisture is transported to India (Liu et al., 2004). Therefore, the PMIP2 OA simulations produce less increase in Indian monsoon rain than the PMIP1 simulations with SST prescribed to the modern values. Zhao (personnal communication) further suggests that the colder than present day SST anomaly in spring in the Arabia Sea leads to less moisture supply and thereby to a decreased of Indian monsoon precipitation.

\subsection{Vegetation feedback}

The three new PMIP2 simulations with interactive vegetation only slightly increase rainfall compared to OA simulations (see Part 1). Figure 5 compares the change in JJAS air temperature and precipitation between the three OAV simulations and their OA counterparts. All three models consistently suggest larger change in temperature north of $50^{\circ} \mathrm{N}$, suggesting an active feedback in these latitudes between the northward migration of the forest to the north, the reduction of sea-ice and snow covers, the surface albedo and temperature (Sect. 4). South of $50^{\circ} \mathrm{N}$ results are model dependent, with a slight tendency for cooler changes in temperature with the OAV version of the models for FOAM and UBRISHadCM3M2. The enhancement of precipitation in Africa is less important for these two models (Fig. 5).

Part of the difference is due to the differences between the OA and OAV control experiments for the same model. Indeed, in order to quantify the vegetation feedback without ambiguity, one should compare the OAV 6 ka experiment with an OA $6 \mathrm{ka}$ experiment for which the preindustrial vegetation simulated in the OAV $0 \mathrm{ka}$ experiment is prescribed as boundary conditions, as suggested by the PMIP2 protocol. These simulations are, however, not yet available in the PMIP2 database. Here for a given model, the OA $6 \mathrm{ka}$ and OAV 6ka simulations do not share the same control simulation. The three models (ECBilt-CLIO-VCODE, FOAM and UBRIS_HadCM3M2) simulate 4\%, $13 \%$ and 19\% respectively less precipitation in the monsoon region in the OAV 0ka simulations compared to the corresponding OA 0 ka simulation (Fig. 5), event though the patterns over west Africa for $6 \mathrm{ka}$ show regions with higher precipitation. As 

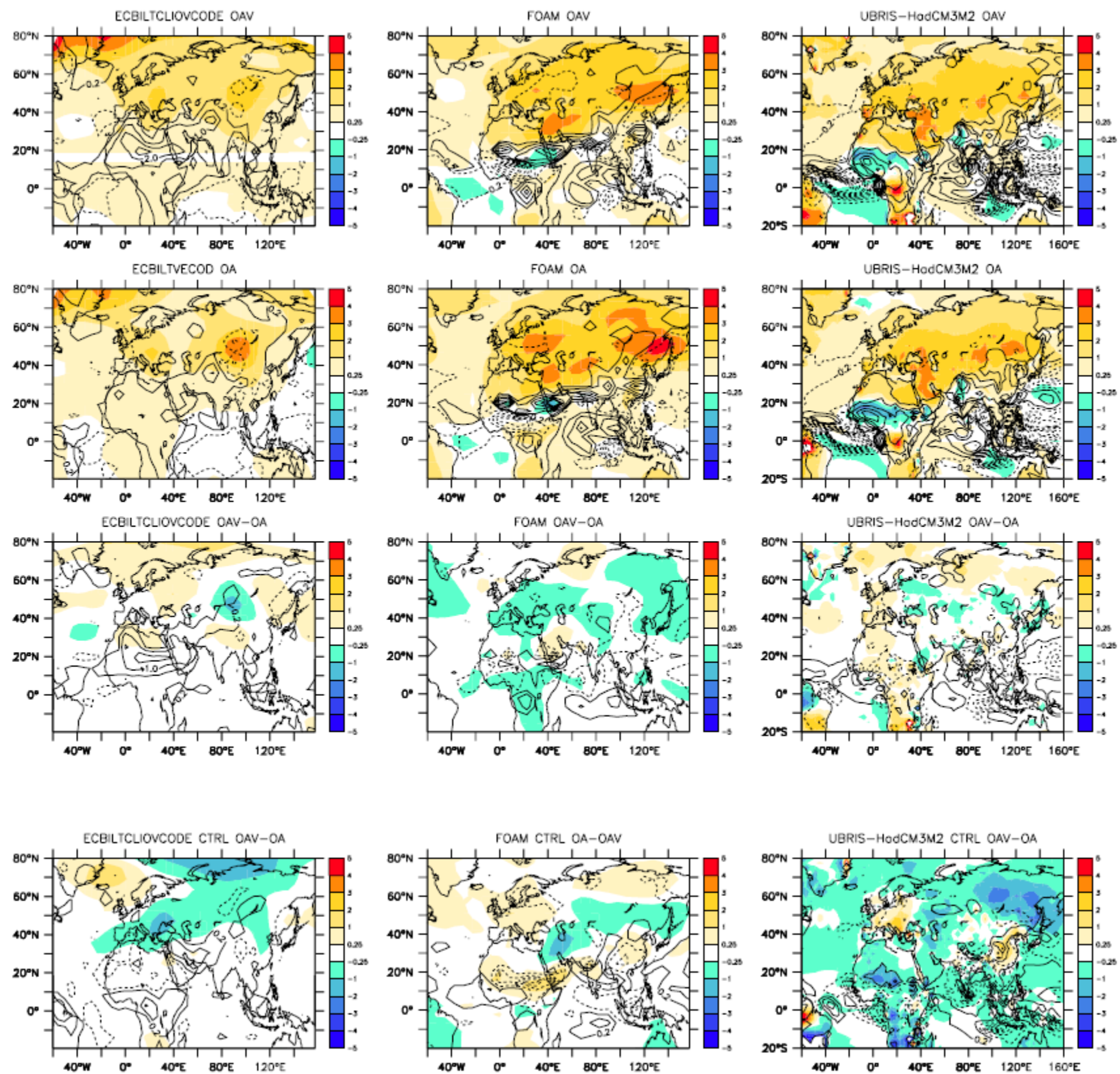

Fig. 5. MH JJAS difference in $2 \mathrm{~m}$ air temperature $\left({ }^{\circ} \mathrm{C}\right.$, color map) and precipitation ( $\mathrm{mm} / \mathrm{d}$, isolines) for the three models for which $\mathrm{OA}$ and OAV simulations are available in the PMIP2 database. The first two lines represent the MH differences simulated by the OA and the OAV simulations respectively, the third lines is the difference between the first two, and the last line represents the differences between OAV and OA for the preindustrial simulations.

an example, UBRIS_HadCM3M2 produces less precipitation for $0 \mathrm{ka}$ along the coast and more precipitation in the interior of the continent to the north of Lake Chad in the OAV version of the model. The differences in $0 \mathrm{ka}$ temperature and in precipitation between $\mathrm{OAV}$ and $\mathrm{OA}$ are as large as the difference between $\mathrm{MH}$ and preindustrial for the three models considered here (Fig. 5). The interactive vegetation in the control climate induces land surface conditions in favour of a colder and dryer climate. The same processes may operate in the Mid-Holocene simulation, explaining why the impact of vegetation is small. For example, we should investigate the role of the soil moisture and of the interactions between vegetation and soil, which were shown by Levis et al. (2004) to limit the monsoon amplication by the interactive vegetation. Additional analyses are needed to fully understand this result. 


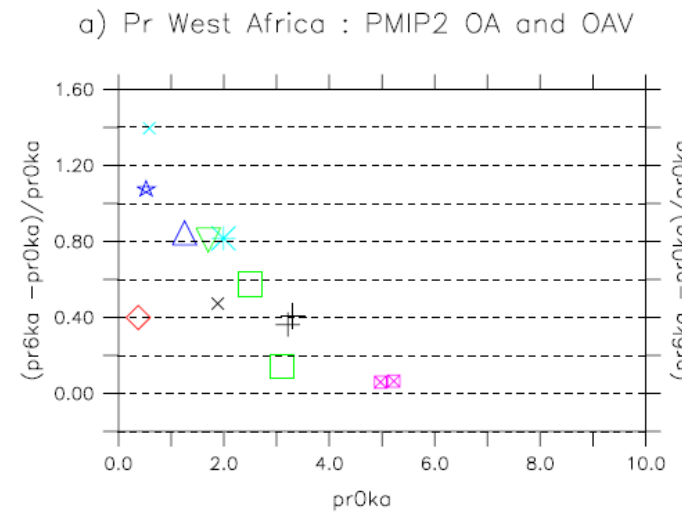

b) Pr West Africa : PMIP1 SSTf

c) North India : PMIP2 OA and OAV

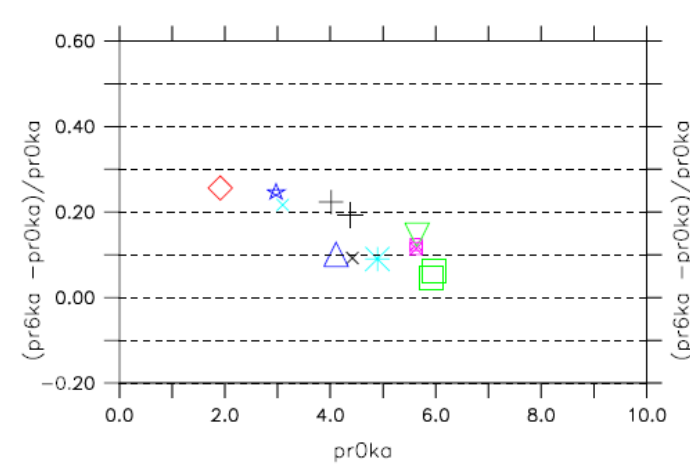

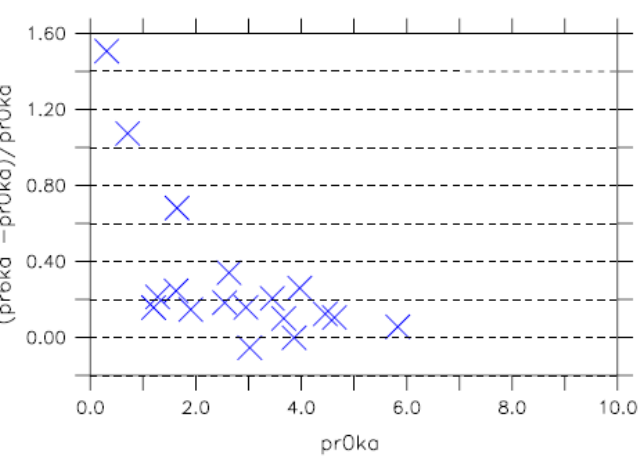

d) North India : PMIP1 SSTf

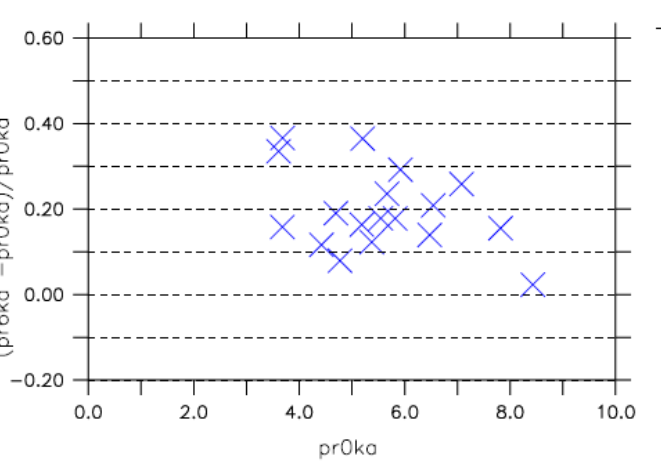

$\times$ CCSM

EECBILTCLIOVECODE

$\triangle$ ECHAM5-MPIOM 1

FGOALS $-1.0 \mathrm{~g}$

$\triangle$ FOAM

$\triangle \mathrm{PSL}-\mathrm{CM} 4-\mathrm{V} 1-\mathrm{MR}$

$\nabla$ MIROC 3.2

\&MRI-CGCM2.3.4fo

$\times$ MRI-CGCM2.3.4nfa

+ UBRIS-HadCM3M2

PMIP2OAV

ECBILTCLIOVECODE

$\triangle$ FOAM

+ UBRIS-HadCM3M2

Fig. 6. Relationship between the Mid-Holocene change in precipitation (ratio of difference to control) and control precipitation (mm/d) for the Sahel (top panel) and North Indian (bottom panel) boxes and (a) PMIP2 OA simulations, (b) PMIP1 SSTf simulations, (c) PMIP2 OA simulations, (d) PMIP1 SSTf.

\subsection{Link with the control simulation}

Model biases or differences between the control experiments need to be considered to understand the response of various models, considering both the pattern and the magnitude of the changes (Braconnot et al., 2002b). Several studies have attempted to relate the change in precipitation simulated for past conditions to model characteristics for present day. For example Joussaume et al. (1999) show that the PMIP1 models that produce the change in precipitation the furthest north over Africa are also those that simulate the present-day ITCZ the furthest north. However, it was not possible to establish a clear relationship between the amount of precipitation simulated for the control simulation and the amount of precipitation change for Mid-Holocene in the PMIP1 models (Braconnot et al., 2000a; Braconnot et al., 2002a). Interestingly, there is a correlation for the PMIP2 OA simulations over these two regions (Fig. 6), though the relationship is counter intuitive. Models that produce the largest precipitation for present day tend to produce less relative change to the control simulation for Mid-Holocene. The differences found between PMIP1 and PMIP2 simulations could reflect the fact that the change precipitation over Africa is primarily due to changes in large scale advection. In the case of the couple simulation the inverse relationship suggests that the model spread is primarily due to the control simulation. For a rather similar change in advection the ratio to the control simulation is smaller for larger control. In coupled experiments the large-scale circulation and the local changes in deep convection over Africa are consistent, so that for a given model there is a relationship between SST, the amount of moisture advected over the Sahel region, convection and precipitation. This is not the case in PMIP1 simulations. In that case the prescribed SST may be incompatible with the heat fluxes and the wind stresses simulated by the atmospheric model for Mid-Holocene over the ocean, and therefore, could in some of the models reinforced or damp inland advection. Such relation ship is also not found for the LGM. For this climate the change in monsoon rain is not so directly attributed to changes in the land sea contrast and moisture advection. The large scale circulation is not as well constraint as for the $\mathrm{MH}$ by dynamical processes and local thermodynamical effects may be dominant.

The surface albedo of the control experiment is another important factor controlling the northward extension of the ITCZ. Charney (1975) indeed suggested that a brighter hot 


\section{ALBEDO in W. Africa}

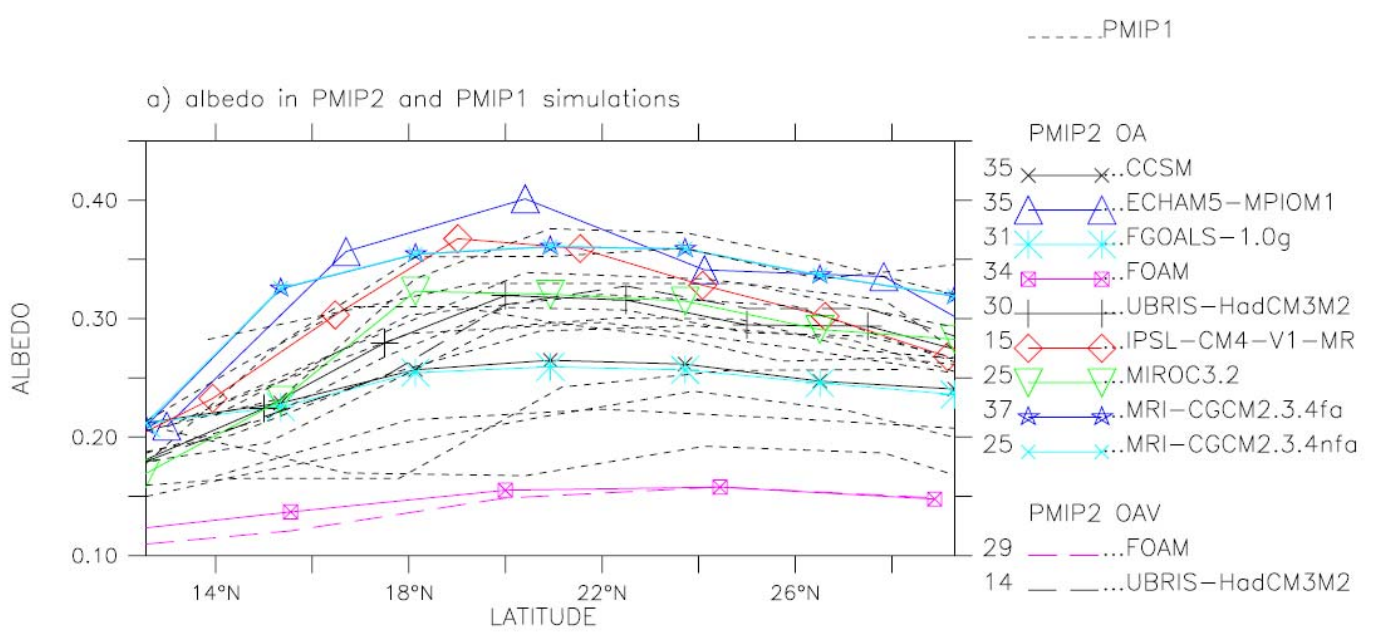

b) albedo and location of the ITCZ

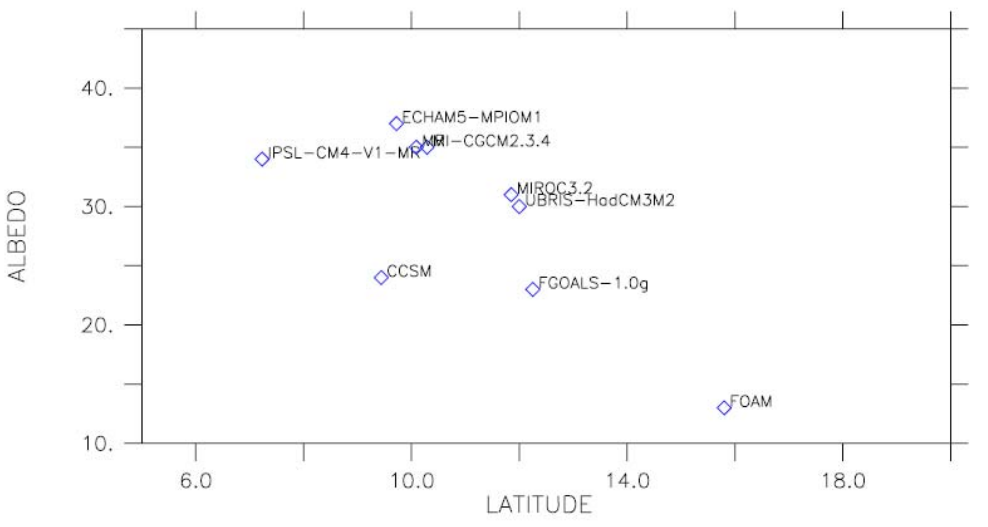

Fig. 7. (a) Surface albedo (ratio) of the control simulation averaged from $20^{\circ} \mathrm{W}$ to $30^{\circ} \mathrm{E}$ and plotted as a function of latitude. The different color lines correspond to the PMIP2 OA simulations. The dotted lines correspond to the set of PMIP1 SSTf simulations. (b) Relationship between the mean surface albedo (\%) of the region extending from $18^{\circ} \mathrm{N}$ to $26^{\circ} \mathrm{N}$ and $20^{\circ} \mathrm{W}$ to $30^{\circ} \mathrm{E}$ and the location of the mean core of the ITCZ (degrees of latitude) over West Africa averaged from $20^{\circ} \mathrm{W}$ to $30^{\circ} \mathrm{E}$ and diagnosed following the definition of Sect. 2.1 from the pre-industrial simulations.

desert would lead to decreased absorbed solar radiation at the surface and a more stable air column that would tend to suppress rainfall. This mechanism has been investigated in several sensitivity experiments for the modern climate and MH (Street Perrott et al., 1990; Bonfils et al., 2001). Following Bonfils et al. (2001), we show in Fig. 7 the surface albedo of the different control simulations, estimated from the shortwave fluxes at the surface, and the relationship across models between the desert albedo and the location of the ITCZ for the control simulations. This figure shows that the PMIP2 OA simulations encompass a large range of surface albedo, with one model (FOAM) exhibiting very low values for this region (Fig. 7a). If we exclude this model, the range covered by the coupled simulations is equivalent to the one of the PMIP1 simulations. Also Fig. 7b confirms that the albedo is a one of the key factor in determining the location of the ITCZ, event though the model spread suggests that other factors, such as the large-scale dynamics and the inflow of moist static energy from the ocean (Su and Neelin, 2005), also play a large role. Interestingly, the fact that the ITCZ is located further north in the UBRIS-HadCM3M2 OAV simulation could be due to the lower albedo in this simulation between $14^{\circ} \mathrm{N}$ and $18^{\circ} \mathrm{N}$ compared to the $\mathrm{OA}$ simulation (Fig. 7a). 

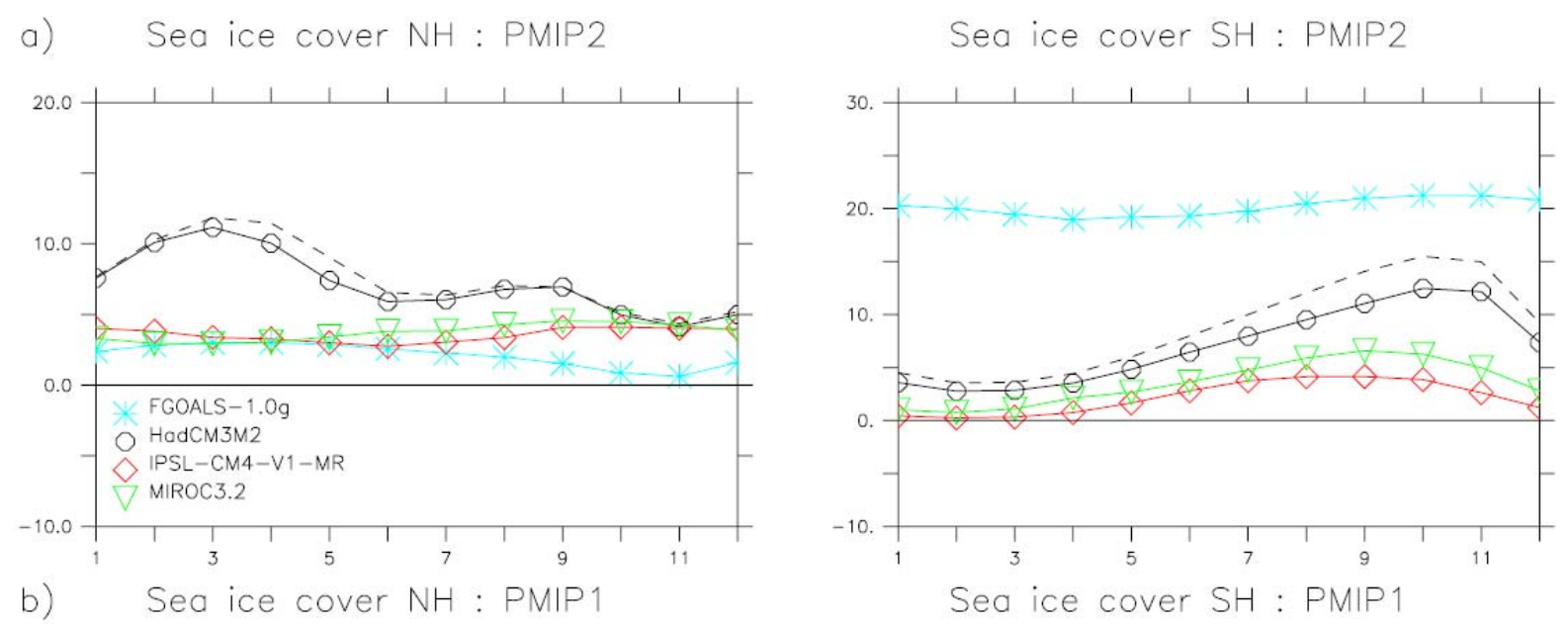

b) Sea ice cover NH: PMIP1
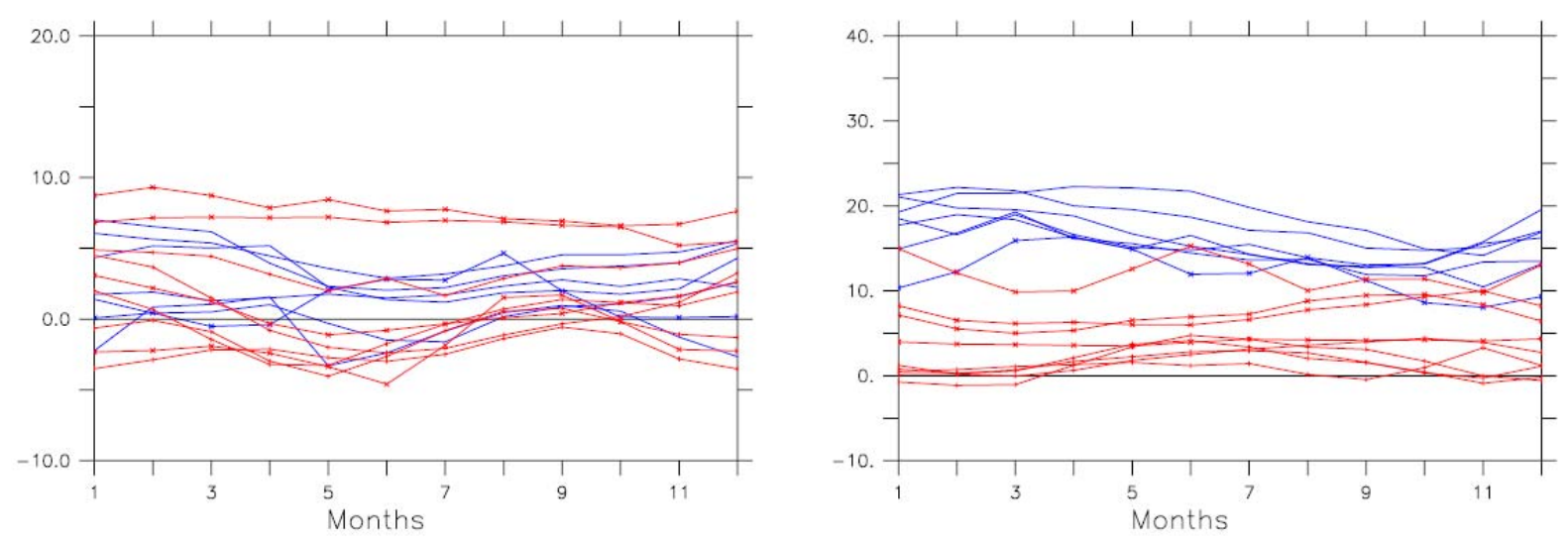

Fig. 8. Change in Sea-ice area (ratio of grid cell covered by sea ice) during the LGM as a function of months for the NH (left) north of $30^{\circ} \mathrm{N}$ and the SH south of $30^{\circ} \mathrm{S}$ (right). (a) PMIP2 OA (symbol colour lines) and OAV (dashed colour lines) experiments, (b) PMIP1 SSTf (blue) and SSTc (red experiments).

\section{Mid and high latitudes change in snow and sea-ice covers}

\subsection{Last Glacial Maximum}

In addition to the increased continental ice sheets at the LGM compared to the preindustrial period, the LGM simulations produce increased snow cover ranging from $10 \%$ to $30 \%$ (not shown). In PMIP1, however, the changes in snow cover are about $10 \%$ smaller than in the OA models and exhibit no seasonal variation (not shown).

The sea ice area in the NH is also increased in the PMIP2 OA LGM simulations, by about $5 \%$ in 3 models (Fig. 8). One simulation (HadCM3M2) exhibits a larger change (up to $10 \%$ ) from January to October. In the SH, all OA models, except one (FGOALS), suggest a change in the sea-ice seasonal cycle with large increases in October-November. FGOALS produces a uniform $20 \%$ increase with no seasonal cycle. The major difference with PMIP1 experiments is the seasonality of the change. In PMIP1, even though the same bound- ary conditions were imposed in all the models, the interpolation on the model grid and in time between the minimum and maximum values provided by CLIMAP lead to slightly different sea-ice cover from one model to the other, reaching as much as a $10 \%$ difference (Fig. 8 bottom, blue curves). Interestingly, in the SH, sea-ice was larger during austral summer and smaller during austral winter in the PMIP1 SSTf simulations than in the PMIP2 OA simulations. This is due to the mean increase in sea-ice cover reconstructed in CLIMAP in a region where the data coverage is poor, which suggest less melting in summer. The PMIP2 simulations still produce substantial melting in summer. On the other hand, SSTc simulations produced very different sea-ice cover with some of the models suggesting up to $25 \%$ more sea-ice in $\mathrm{NH}$ (red curves). Note also that in both hemispheres, the only PMIP2 simulation with interactive vegetation (HadCM3M2, black dashed line) produces enhanced sea ice (by a few \%) compared to the corresponding OA simulation, consistent with the colder conditions in this simulation (Crucifix et al., 2005). 


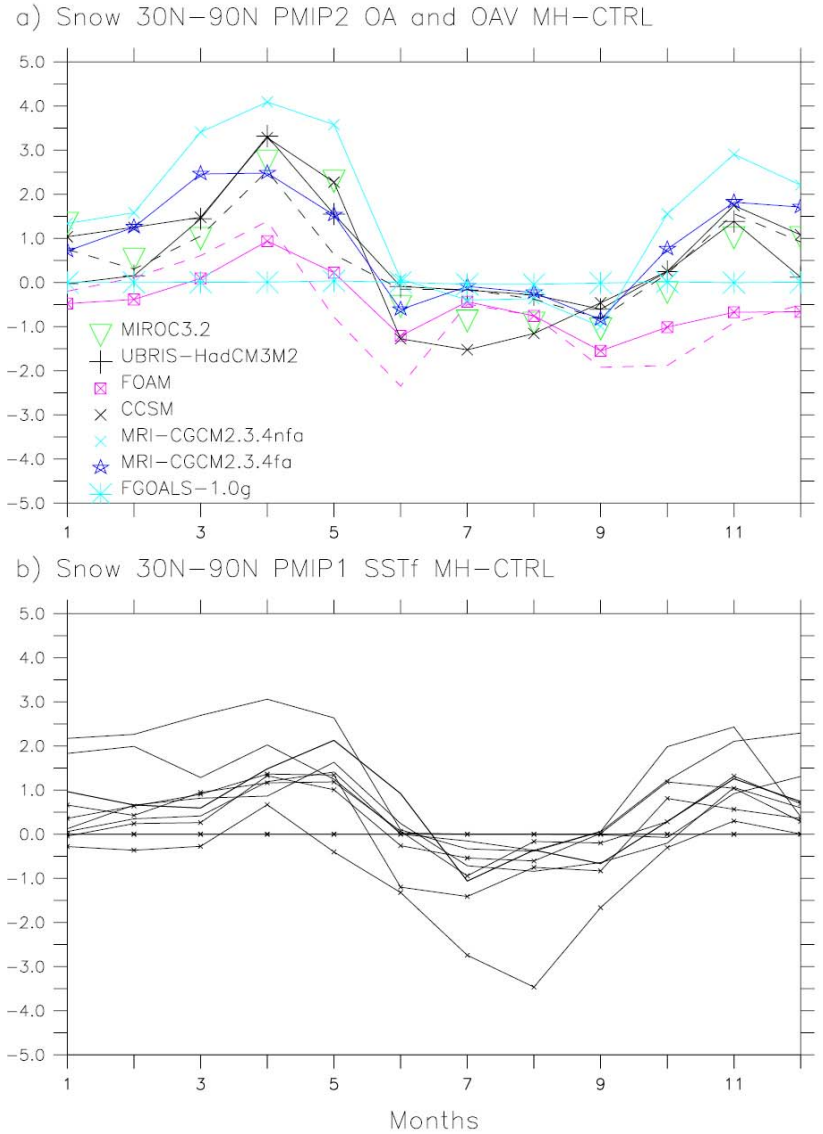

Fig. 9. Mean seasonal evolution of the change in $\mathrm{NH}$ snow cover (ratio) simulated from $30^{\circ} \mathrm{N}$ to $90^{\circ} \mathrm{N}$ by (a) PMIP2 OA (symbol colour lines) and OAV (dashed colour lines) experiments and (b) PMIP1 SSTf experiments (black lines).

\subsection{Mid-Holocene}

During the $\mathrm{MH}$, changes in snow and sea-ice covers are more contrasted from one season to the other, following the changes in insolation. The general feature simulated by both PMIP2 OA and PMIP1 SSTf corresponds to a larger snow cover from March to May in the NH compared to the control (Fig. 9), due to the smaller insolation. In boreal summer the melting is larger than today. The change in the building up of the snow cover from October to May occurs in two main phases, one in October-November and the other one from February to May. PMIP2 OA simulations produce a larger enhancement of the snow cover in spring than PMIP1 SSTf (Fig. 9). This can be attributed to the colder conditions induced by the ocean response to the insolation forcing in spring and the advection of colder air on the continent. However, the retreat of the snow pack occurs earlier and conditions with less snow than today last until October. This latter point is consistent with the late warming of the ocean in autumn, which favours warmer conditions in the NH. Simu- lations with interactive vegetation enhance this feature, certainly due to the warmer condition in mid and high latitudes favoured by the northward migration of forest (Harrison et al., 1998; Kaplan et al., 2003; Wohlfahrt et al., 2004).

Changes in sea ice cover for the MH OA simulations are shown in Fig. 10. The sea-ice cover is slightly reduced year round in the NH in all PMIP2 OA simulations except one (ECBiltCLIOVECODE, Fig. 10), which has a pronounced decrease (2 to $25 \%$ ) during summer and early autumn (JASO). In the SH, sea-ice cover is less affected by insolation changes, except for one simulation where it is reduced by about $10 \%$. However the slight decrease of sea-ice during DJF is consistent with increased insolation in high latitude resulting from the larger obliquity. Indeed, even though precession contributes to damp the seasonal cycle in the $\mathrm{SH}$, obliquity increases it annually and seasonally.

These analyses suggest that for the $\mathrm{NH}$, snow cover changes during the Mid-Holocene should have a major impact in spring, whereas sea-ice changes should have a larger impact during summer. Changes in snow and sea-ice should not affect the radiative budget of mid- and high latitudes in the SH.

\section{Radiative impact of snow and sea-ice covers}

\subsection{Simple diagnostics}

In order to check if we can detect the impact of the changes in snow and sea-ice covers on the radiative budget of midand high latitudes, we compute the change in radiative heat budget at the top of the atmosphere (TOA) averaged from $30^{\circ} \mathrm{N}$ to $90^{\circ} \mathrm{N}$ and $30^{\circ} \mathrm{S}$ to $90^{\circ} \mathrm{S}$ respectively:

$$
\Delta \mathrm{TOA}=\left(S W n_{\mathrm{pal}}-S W n_{0 \mathrm{k}}\right)-\left(L W n_{\mathrm{pal}}-L W n_{0 \mathrm{k}}\right)
$$

where $\triangle T O A$ represents the change in net radiative heat flux at the top of the atmosphere, $S W n$ represents the net shortwave radiation at the top of the atmosphere (positive downward) and $L W n$ the net longwave radiation (positive upward). The indices pal refers to the past period considered $(21 \mathrm{ka}$ or $6 \mathrm{ka}$ ). In this analysis we consider only the three models (CCSM3, IPSL-CM4-MR, MIROC3.2) for which radiative fluxes for all sky and clear sky $(c s)$ are available in the database for the two time periods. We also make simple diagnoses to obtain the first order of magnitude of the way changes in snow and sea ice covers affect $\Delta S W n$ and $\Delta L W n$. We quantify the role of clouds using the cloud radiative forcing $(c r f)$ :

$$
\begin{aligned}
& c r f=\mathrm{TOA}-\mathrm{TOA} c s, \quad \operatorname{crf} S W=S W n-S W n c s, \\
& \text { and } \quad c r f L W=L W n-L W n c s
\end{aligned}
$$

A more complete heat budget should also consider the heat transport at the equatorward boundary of each region, but we do not consider this aspect here. As a first approximation we assume that the paleo change in shortwave for clear sky is 

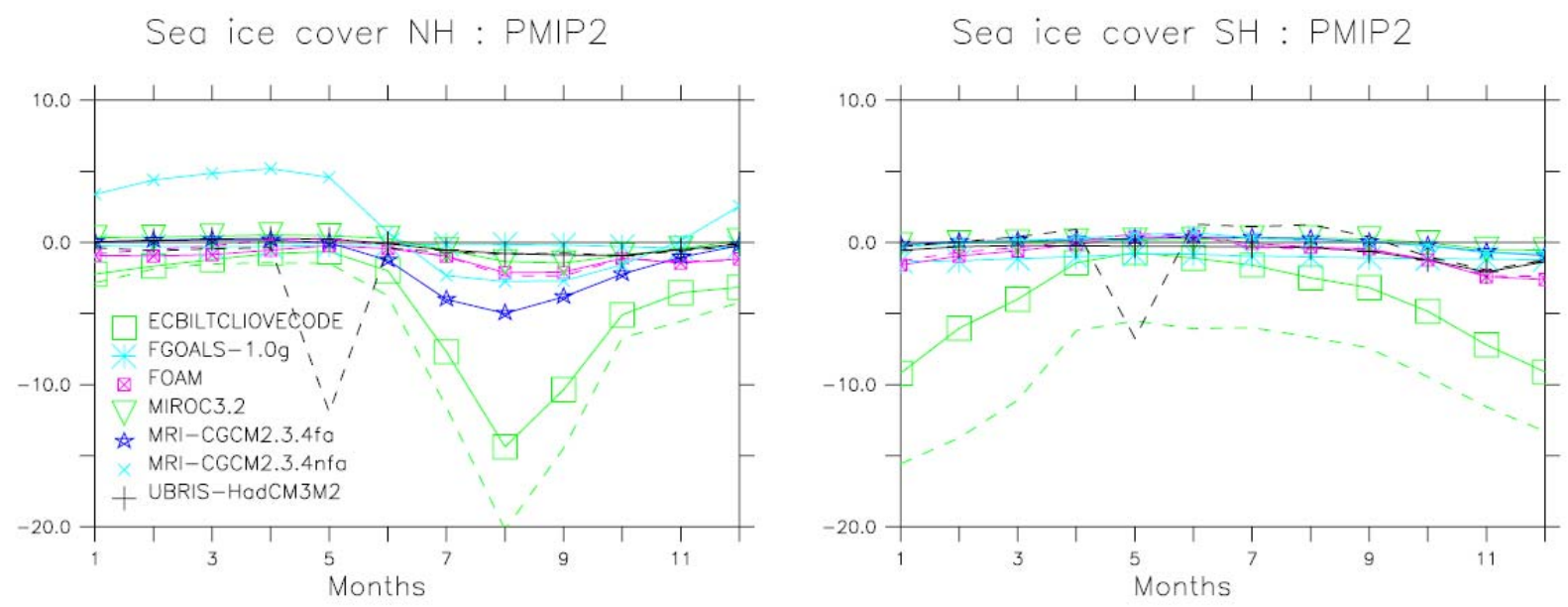

Fig. 10. Same as Fig. 8, but only for PMIP2 OA MH simulations.

primary due to surface albedo. Even though the same change in insolation $(\Delta S W i)$ is provided to all models at the top of the atmosphere, the forcing is different among the models because they use different planetary albedo values for the preindustrial control simulation $\left(\alpha_{0 \mathrm{k}}\right)$. The shortwave forcing $(S W f)$ is estimated following Hewitt and Mitchell (1996):

$S W f=\left(1-\alpha_{O \mathrm{k}}\right) \Delta S W i$

This effect has to be accounted for to estimate the change in SWncs induced by changes in snow and sea-ice covers. The latter is thus provided by:

Albedo effet $=\left(S W n c s_{\mathrm{pal}}-S W n c s_{0 \mathrm{k}}\right)-S W f$,

In addition, it is difficult with standard model output to make a clear estimate of the role of water vapour and of temperature on the longwave flux. We make the assumption that the difference between the clear sky emission at the surface and at the top of the atmosphere represents the greenhouse effect (or gain) of the atmosphere $(g)$. The greenhouse effect is mostly affected by greenhouse gases and water vapour. The effects of the change in surface temperature $(T)$ and of the atmospheric greenhouse effect on $L W n$ are then simply estimated by (Meehl et al., 2004):

$\Delta$ emis $T=4 \sigma T_{0 \mathrm{k}}^{3}\left(T_{s \mathrm{pal}}-T_{s 0 \mathrm{k}}\right) \quad$ and

$\Delta g=\left(\sigma T_{s}^{4}-L W n c s\right)_{\mathrm{pal}}-\left(\sigma T_{s}^{4}-L W n c s\right)_{0 \mathrm{k}}$

\subsection{Results for the Last Glacial Maximum}

These estimates are plotted for LGM and MH on Fig. 11 for NH. Several features emerge from these figures. First, at the LGM the net clear sky heat flux at TOA is negative in annual mean for the region north of $30^{\circ} \mathrm{N}$, but this masks a slight increase in TOA from October to March (Fig. 11a). The reason for this positive change in TOAcs is that the albedo of the ice-sheet has only a small impact during winter, since solar radiation is very small (Fig. 11). Therefore the signal is dominated by the reduction of longwave emission. The latter is nearly constant over the year $\left(-10\right.$ to $\left.-15 \mathrm{~W} / \mathrm{m}^{2}\right)$. During March to September the change in shortwave radiation is dominant. Since there is nearly no change in insolation for this period compared to preindustrial this change is due to the increased surface albedo and contributes to the net cooling of the system (about $-40 \mathrm{~W} / \mathrm{m}^{2}$ in June-July, Fig. 11c). Estimations of the ice-sheet forcing using the approximate partial radiative perturbation method developed by Taylor et al. (2007) and used by Crucifix (2006) vary from -7 to $-14 \mathrm{~W} / \mathrm{m}^{2}$ in annual mean depending on the model. The ice-sheet therefore contributes about $25 \%$ of the albedo effect (Fig. 11c) and the increased snow and sea ice covers account for the remaining $75 \%$. Therefore we estimate from Fig. 11c that the feedback involving snow and sea ice varies from about $3 \mathrm{~W} / \mathrm{m}^{2}$ during boreal winter to about $30 \mathrm{~W} / \mathrm{m}^{2}$ during boreal summer. This effect is larger than the effect of the changes in cloud estimated by the cloud radiative forcing (Fig. 11b). Note however that estimations of cloud radiative forcing are ambiguous over highly reflecting surfaces (Bony et al., 2006). The change in the cloud radiative forcing suggests a relatively small impact of the change in clouds on the heat budget, with a tendency to counteract the radiative cooling (Fig. 11b). Our rough estimates of the origin of the change in the longwave heat flux at TOA also suggest that the dominant term is due to the surface cooling (emis, $-30 \mathrm{~W} / \mathrm{m}^{2}$; Fig. 11c). The reduction of the atmospheric heat gain, resulting from reduced $\mathrm{CO}_{2}$ concentration and water vapour represents half this value (Fig. 11c). Therefore this suggests that the ice-sheet albedo, and the $\mathrm{CO}_{2}$ and water vapour each contribute equal parts of the cooling of the $\mathrm{NH}$, north of $30^{\circ} \mathrm{N}$.

Conditions are different over the $\mathrm{SH}$ (south of $30^{\circ} \mathrm{S}$ ) where changes in the LGM net heat budget are much smaller 

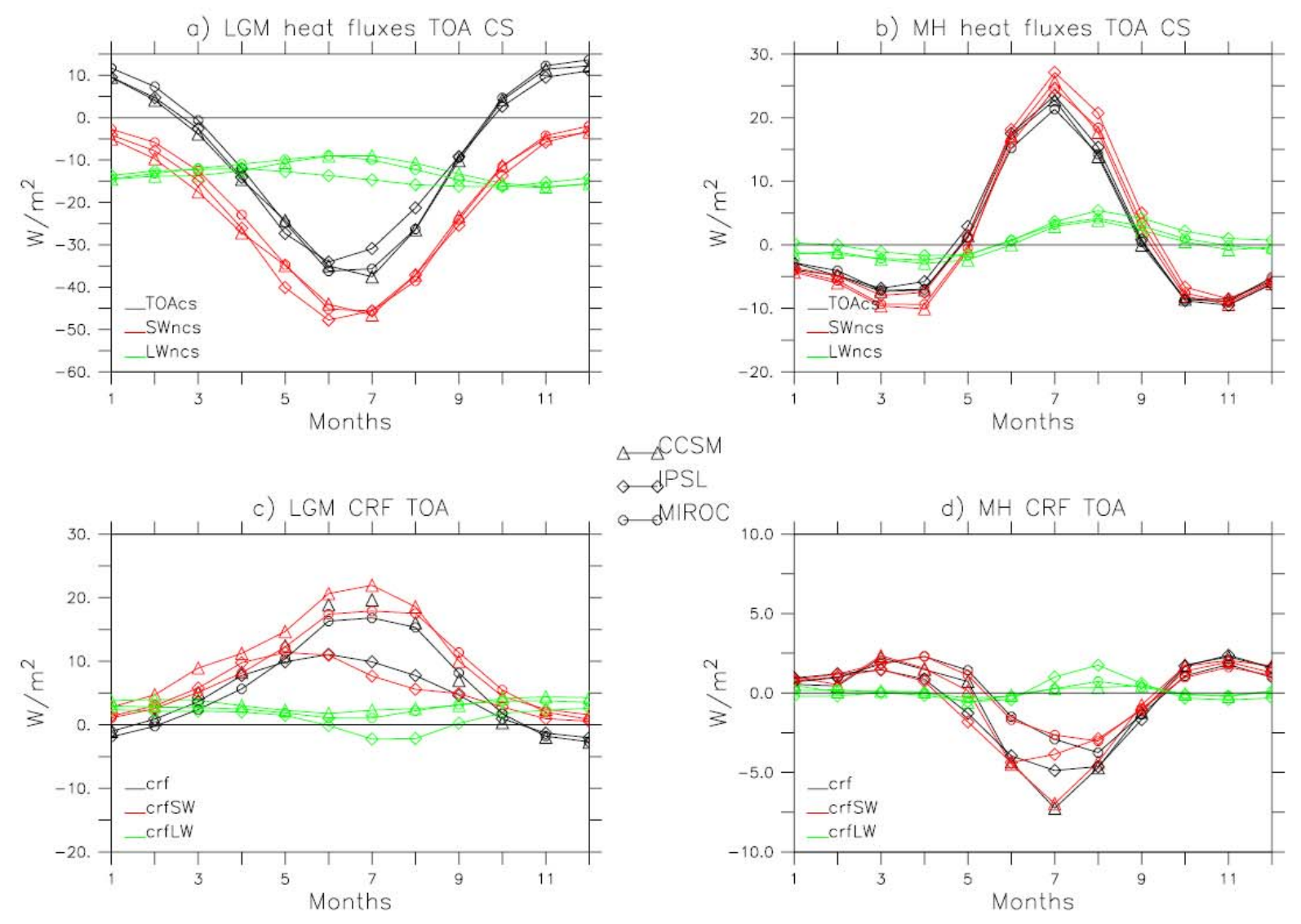

$\triangle \triangle$ CCSM
$\diamond$ dPSL
$\circ$ dMIROC
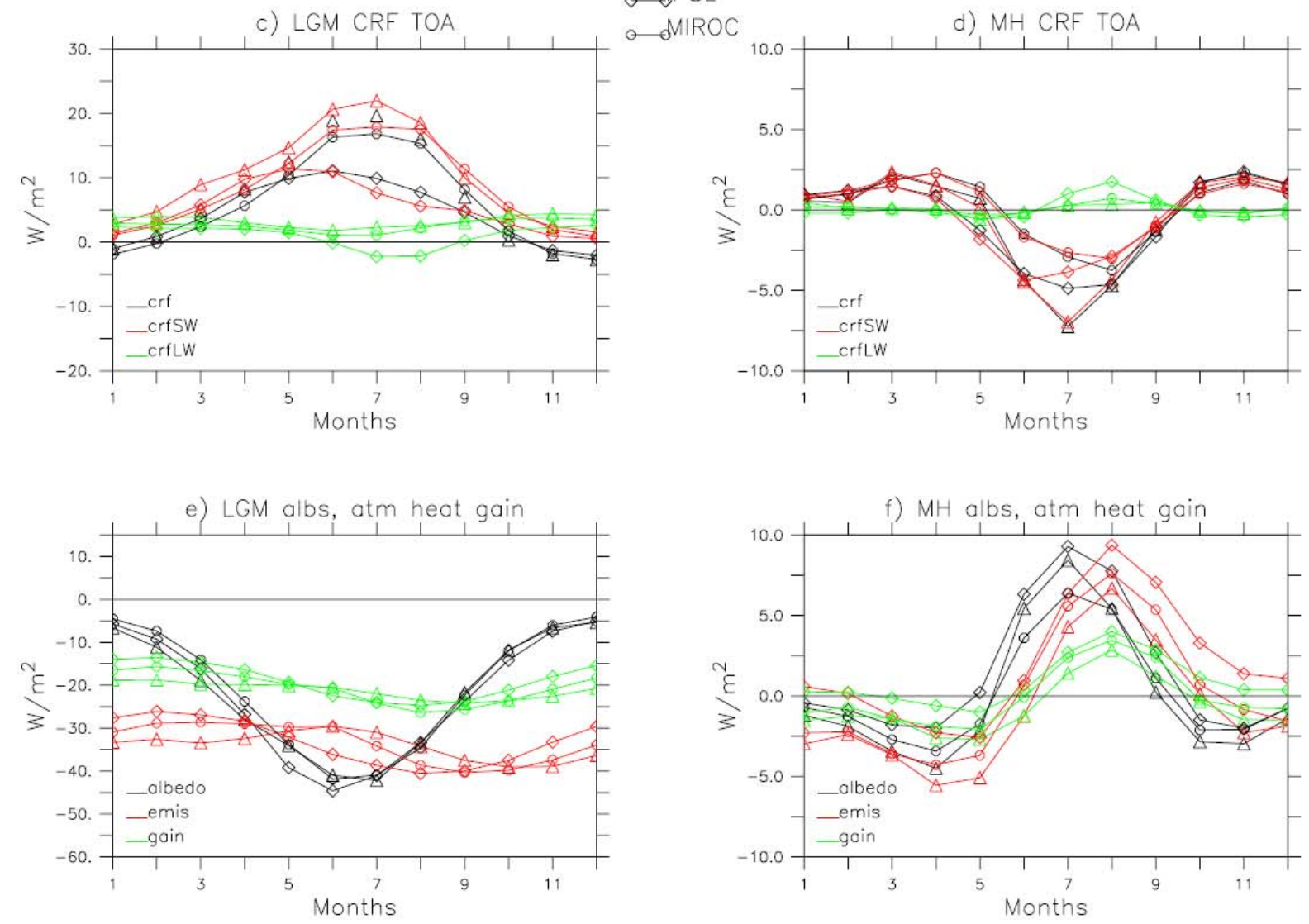

Fig. 11. Change in radiative heat budget $\left(\mathrm{W} / \mathrm{m}^{2}\right.$ ) averaged from $30^{\circ} \mathrm{N}$ to $90^{\circ} \mathrm{N}$ for a subset of PMIP2OA simulations (CCSM, triangles; IPSL squares; MIROC, circles). (a) changes in LGM clear sky heat budget (TOAcs, black, positive downward), clear sky shortwave (SWncs, red, positive downward) and clear sky longwave (LWncs, green, outgoing radiation positive upward) (b) change in LGM cloud radiative forcing ( $c r f$, black, positive down ward), with the short wave ( $c r f S W$, red) and longwave ( $c r f L W$, green) contributions, and (c) contribution of the surface albedo on the shorwave radiation (albedo, black, positive downward), change in LW emission due to change in surface temperature (emis, red, positive upward), and change in the atmospheric heat gain (gain, green, positive downward) for LGM. (d), (e) and (f) same as (a), (b), (c), but for the MH.

(not shown). The reason is that changes in ice-sheets and sea ice covers are less effective (Fig. 8). For these latitudes, the surface albedo has only small impact, except for the model that has the largest change in sea-ice cover. In these SH lat- itudes, the reduction of the atmospheric heat gain is as large as the surface cooling, which suggests that $\mathrm{CO}_{2}$ and water vapour contribute most to the cooling. This is consistent with several studies suggesting that the polar amplification over 
Antarctica may provide useful evidence on climate sensitivity (Manabe and Broccoli, 1985; Masson-Delmotte et al., 2006), although the relationship is complex (Crucifix, 2006; Hargreaves et al., 2007).

\subsection{Results for the Mid-Holocene}

For the $\mathrm{MH}$, changes in SWn also provide the dominant contribution to the seasonal heat budget of the mid- and high latitudes (Fig. 11d), primarily from changes in solar forcing. The net heat flux is thus reduced during winter north of $30^{\circ} \mathrm{N}$ and enhanced during summer. For both seasons, the changes in cloud forcing tend to counteract the solar forcing and surface albedo feedback (Fig. 11e). Figure 11f shows that the albedo effect (Eq. 7) involving feedbacks from snow and sea ice leads to about 2 to $5 \mathrm{~W} / \mathrm{m}^{2}$ additional reduction in SWncs in March (when snow cover is enhanced compared to present day) and an additional increase of about $5 \mathrm{~W} / \mathrm{m}^{2}$ during boreal summer when sea ice cover is reduced (Fig. 10). The change in long wave radiation due to the change in temperature lags by about one month the insolation forcing and ice and snow SW feedbacks (Fig. 11f). The decreased sea ice cover and the surface warming during boreal summer also have an impact on the atmospheric heat gain. Changes in the atmospheric heat gain show a slight reduction in May and an increase during boreal summer when temperature is at its maximum. This results in increased temperature and increased water vapour in these regions. They occur after the summer solstice, which is consistent with the response of sea-ice to increased summer insolation (Khodri et al., 2005). This effect is important compared to the magnitude of the other fluxes, and shows that water vapour feedback at high latitudes in the NH strengthens the warming. Similar lags between solar radiation, the role of surface albedo, temperature and water vapour are seen in the SH although of smaller magnitude.

\section{Conclusions}

We analyse several aspects of the simulated LGM and MH climates from PMIP2 set of simulations, focussing on feedbacks from ocean, vegetation, snow and sea ice covers and on their impact on the location of the ITCZ in the tropical regions and on the heat budget in mean and high latitudes.

The position of the ITCZ varies only by a few degrees at LGM compared to its modern position. Several models suggest a slight southward shift, more pronounced over the continents, and on both sides of the Panama isthmus. Broccoli et al. (2006) and Zhang and Delworth (2005) attribute this shift to the changes in the differential heating between the two hemisphere induced by the cold conditions in the Atlantic. However, over most of the oceans, the simulated changes in LGM SST are quite uniform so that PMIP2 OA simulations exhibit a small northward extent of the ITCZ over the West
Pacific. This shift is larger in PMIP1 LGM experiments, because of the presence of the warm pool in the CLIMAP SST reconstruction. Precipitation is also slightly reduced in the northern part of the ITCZ. The atmospheric water vapour is also reduced in mid and high latitudes. This reduction, together with the reduction of the atmospheric $\mathrm{CO}_{2}$ concentration, contributes to the cold LGM climate. In the $\mathrm{NH}$ the large ice-sheet albedo is the dominant forcing term. We estimate that for latitudes north of $30^{\circ} \mathrm{N}$ the feedback from changes in snow and sea-ice covers represents about twice the ice-sheet forcing. Albedo has thus a dominant role in the $\mathrm{NH}$ cooling and the reduction of the atmospheric greenhouse effect contributes to only $50 \%$ of the albedo effect. In the SH, on the other hand, albedo changes are small and the cooling is mainly driven by reduced $\mathrm{CO}_{2}$ and water vapour. These conclusions are consistent with previous estimations (Hansen et al., 1984; Hewitt and Mitchell, 1997; Shin et al., 2003; Jahn et al., 2005; Otto-Bliesner et al., 2006). Additional work and additional LGM simulations would be needed to fully assess if LGM polar amplification and paleo data in this region could provide a good constraint on climate sensitivity. Results from ensemble simulations with varying parameters suggest that LGM simulations provide some constraint, but with varying level of success depending on the model complexity and experimental protocol (Annan et al., 2005; Schneider von Deimling et al., 2006a; Schneider von Deimling et al., 2006b). In addition Crucifix (2006)found an inverse relationship between LGM polar amplification over Antarctica and climate sensitivity. The reason for it needs further investigation.

For $\mathrm{MH}$, the monsoons are enhanced both over West Africa and over the north of India. In these regions our analysis of the location of the ITCZ shows that the ITCZ shifts by several degrees northward and that precipitation is enhanced in the northern part of the ITCZ. The ocean feedback strengthens the response of the African monsoon and damps the response of the Indian monsoon. This results from different responses of the circulation in the Atlantic and IndianPacific sectors. In both regions, the cold ocean in spring strengthens the land-ocean contrast, and thus the moisture flux from the ocean to the continent. In the Atlantic this contrast is further enhanced by warmer than present SST north of $5^{\circ} \mathrm{N}$ and colder conditions south of $5^{\circ} \mathrm{N}$, which favours a northward shift of the ITCZ over the Atlantic ocean and over the continent. We clearly establish that there is a positive relationship between this ocean response and the change in precipitation over West Africa. The more models enhance the meridional SST gradient in the tropical Atlantic the more they simulate an increase in precipitation over West Africa. Feedbacks from snow and sea ice add to the NH MH cooling (warming) induced by insolation changes in spring (summer) and in summer respectively at mid and high latitudes. Snow feedback is larger in the PMIP2 OA simulations than in the PMIP1 simulations. Also the melting of sea ice in NH during MH boreal summer impacts both surface albedo and the wa- 
ter vapour in the atmosphere. These two effects strengthen the late summer warming induced by the late response of the ocean to the increased insolation.

Our analyses also suggest that some of the differences between PMIP1 and PMIP2 experiments could be attributed to the pre-industrial simulations. For pre-industrial conditions, the PMIP2 OA simulations better reproduce the location of the ITCZ than the previous generation of atmospheric models used in PMIP1. Note, however, that in DJF most of the coupled simulations produce a well marked double ITCZ structure in the east Pacific, and therefore are less satisfactory than the atmosphere alone simulation in this ocean basin for this season. In the PMIP2 OA simulations, a relationship is found for the MH between the ratio of the precipitation change and modern precipitation over West Africa and North India. Such a relationship is not found for PMIP1 simulations, nor for the LGM climate. This needs to be investigated further and stresses that the large-scale dynamics play an important role in redistributing precipitation during the MH. During the LGM, thermodynamics and reduced water vapour in the tropical regions seems to be the leading terms to explain changes in monsoon rain. Finally, it is also not possible to establish a clear conclusion on the role of the vegetation feedback from the OAV simulations. The new PMIP2 OA simulations for the Mid-Holocene confirm that vegetation feedback strengthens the African monsoon and the high latitude warming. However the magnitude of the feedback is smaller than previously discussed. Part of it comes from differences between OA and OAV pre-industrial simulations, and further investigation is needed to provide robust conclusions.

Acknowledgements. We acknowledge the international modelling groups for providing their data for analysis, the Laboratoire des Sciences du Climat et de l'Environnement (LSCE) for collecting and archiving the model data. The PMIP2/MOTIF Data Archive is supported by CEA, CNRS, the EU project MOTIF (EVK2-CT-2002-00153) and the Programme National d'Etude de la Dynamique du Climat (PNEDC). The analyses were performed using version 15/03/2007 of the database. More information is available on http://www-lsce.cea.fr/pmip/ and http://www-lsce.cea.fr/motif/.

Edited by: J. Hargreaves

\section{References}

Annan, J. D., Hargreaves, J. C., Ohgaito, R., Abe-Ouchi, A., and Emori, S.: Efficiently Contraining Climate Sensiticity with Paleoclimate Simulations, SOLA, 1, 181-184, 2005.

Bonfils, C., de Noblet-Ducoure, N., Braconnot, P., and Joussaume, S.: Hot Desert Albedo and Climate Change: Mid-Holocene Monsoon in North Africa, J. Climate, 14, 3724-3737, 2001.

Bony, S., Colman, R., Kattsov, V. M., Allan, R. P., Bretherton, C. S., Dufresne, J. L., Hall, A., Hallegatte, S., Holland, M. M., Ingram, W., Randall, D. A., Soden, B. J., Tselioudis, G., and Webb, M.
J.: How Well Do We Understand and Evaluate Climate Change Feedback Processes?, J. Climate, 19, 3445-3482, 2006.

Braconnot, P., Joussaume, S., Marti, O., and de Noblet, N.: Synergistic Feedbacks from Ocean and Vegetation on the African Monsoon Response to Mid-Holocene Insolation, Geophys. Res. Lett., 26, 2481-2484, 1999.

Braconnot, P., Joussaume, S., de Noblet, N., and Ramstein, G.: Mid-Holocene and Last Glacial Maximum African Monsoon Changes as Simulated within the Paleoclimate Modelling Intercomparison Project, Global Planet. Change, 26, 51-66, 2000a.

Braconnot, P., Marti, O., Joussaume, S., and Leclainche, Y.: Ocean Feedback in Response to $6 \mathrm{Kyr}$ BP Insolation, J. Climate, 13, 1537-1553, 2000b.

Braconnot, P., Loutre, M. F., Dong, B., Joussaume, S., and Valdes, P.: How the Simulated Change in Monsoon at $6 \mathrm{Ka} \mathrm{BP}$ is Related to the Simulation of the Modern Climate: Results from the Paleoclimate Modeling Intercomparison Project, Clim. Dyn., 19, 107-121, 2002a.

Braconnot, P., Loutre, M. F., Dong, B., Joussaume, S., Valdes, P., and PMIP Participating Grps: How the Simulated Change in Monsoon at $6 \mathrm{Ka}$ BP Is Related to the Simulation of the Modern Climate: Results from the Paleoclimate Modeling Intercomparison Project, Clim. Dyn., 19, 107-121, 2002b.

Braconnot, P., Harrison, S., Joussaume, J., Hewitt, C., Kitoh, A., Kutzbach, J., Liu, Z., Otto-Bleisner, B. L., Syktus, J., and Weber, S. L.: Evaluation of Coupled Ocean-Atmosphere Simulations of the Mid-Holocene, in: Past Climate Variability through Europe and Africa, edited by: Battarbee, R. W., Gasse, F., and Stickley, C. E., Kluwer Academic publisher, 515-533, 2004.

Braconnot, P., Otto-Bliesner, B., Harrison, S., Joussaume, S, Peterchmitt, J.-Y., Abe-Ouchi, A., Crucifix, M. , Driesschaert, E., Fichefet, Th., Hewitt, C. D., Kageyama, M., Kitoh, A., Laîné, A., Loutre, M.-F., Marti, O., Merkel, U., Ramstein, G., Valdes, P., Weber, L. ,Yu, Y., and Zhao, Y.: Results of PMIP2 coupled simulations of the mid-Holocene and Last Glacial Maximum Part 1: experiments and large-scale features, Clim. Past, 3, 261277, 2007, http://www.clim-past.net/3/261/2007/.

Broccoli, A. J., Dahl, K. A., and Stouffer, R. J.: Response of the ITCZ to Northern Hemisphere Cooling, Geophys. Res. Lett., 33, L01702, doi:10.1029/2005GL024546, 2006.

Cane, M. A., Braconnot, P., Clement, A., Gildor, H., Joussaume, S., Kageyama, M., Khodri, M., Paillard, D., Tett, S., and Zorita, E.: Progress in Paleoclimate Modeling, J. Climate, 19, 5031-5057, 2006.

Charney, J. G.: Dynamics of Deserts and Drought in Sahel, Q. J. Roy. Meteor. Soc., 101, 193-202, 1975.

Claussen, M. and Gayler, V.: The Greening of the Sahara During the Mid-Holocene: Results of an Interactive Atmosphere-Biome Model, Glob. Ecol. Biogeogr. Lett., 6, 369-377, 1997.

Crucifix, M., Betts, R. A., and Hewitt, C. D.: Pre-IndustrialPotential and Last Glacial Maximum Global Vegetation Simulated with a Coupled Climate-Bio Sphere Model: Diagnosis of Bioclimatic Relationships, Global Planet. Change, 45, 295-312, 2005.

Crucifix, M.: Does the Last Glacial Maximum Constrain Climate Sensitivity? Geophys. Res. Lett., 33, L18701, doi:10.1029/2006GL027137, 2006.

Gadgil, S. and Sajani, S.: Monsoon Precipitation in the Amip Runs, 
Clim. Dyn., 14, 659-689, 1998.

Gordon, C., Cooper, C., Senior, C. A., Banks, H., Gregory, J. M., Johns, T. C., Mitchell, J. F. B., and Wood, R. A.: The Simulation of Sst, Sea-Ice Extents and Ocean Heat Transports in a Version of the Hadley Centre Model without Flux Adjustments, Clim. Dyn., 16, 147-168, 2000.

Haak, H., Jungclaus, J., Mikolajewicz, U., and Latif, M.: Formation and Propagation of Great Salinity Anomalies, Geophys. Res. Lett., 30(9), 1473, doi:10.1029/2003GL017065, 2003.

Hansen, J., Lacis, A. A., Rind, D., Russell, G., Stone, P., Fung, I., Ruedy, R., and Lerner, J.: Climate Sensitivity: Analysis of Feedback Mechanisms, Vol. AGU Geophys. Monograph 29, Climate Processes and Climate Sensitivity, American Geophysical Union. Washington, D.C., 1984.

Hargreaves, J. C., Abe-Ouchi, A., and Annan, J. D.: Linking Glacial and Future Climates through an Ensemble of GCM Simulations, Clim. Past, 3, 77-87, 2007, http://www.clim-past.net/3/77/2007/.

Harrison, S., Braconnot, P., Hewitt, C., and Stouffer, R. J.: Fourth International Workshop of the Palaeoclimate Modelling Intercomparison Project (PMIP): Launching PMIP Phase Ii., EOS, 83, 447-447, 2002.

Harrison, S. P., Jolly, D., Laarif, F., Abe-Ouchi, A., Dong, B., Herterich, K., Hewitt, C., Joussaume, S., Kutzbach, J. E., Mitchell, J., de Noblet, N., and Valdes, P.: Intercomparison of Simulated Global Vegetation Distributions in Response to 6 Kyr BP Orbital Forcing, J. Climate, 11, 2721-2742, 1998.

Haug, G. H., Hughen, K. A., Sigman, D. M., Peterson, L. C., and Rohl, U.: Southward Migration of the Intertropical Convergence Zone through the Holocene, Science, 293, 1304-1308, 2001.

Hewitt, C. D. and Mitchell, J. F. B.: Gcm Simulations of the Climate of 6 Kyr BP: Mean Changes and Interdecadal Variability, J. Climate, 9, 3505-3529, 1996.

Hewitt, C. D. and Mitchell, J. F. B.: Radiative Forcing and Response of a Gcm to Ice Age Boundary Conditions: Cloud Feedback and Climate Sensitivity, Clim. Dyn., 13, 821-834, 1997.

Jacob, R., Schafer, C., Foster, I., Tobis, M., and Andersen, J.: Computational Design and Performance of the Fast Ocean Atmosphere Model: Version 1. In: The 2001 International Conference on Computational Science., pp. 175-184, 2001.

Jahn, A., Claussen, M., Ganopolski, A., and Brovkin, V.: Quantifying the Effect of Vegetation Dynamics on the Climate of the Last Glacial Maximum, Clim. Past, 1, 1-7, 2005,

http://www.clim-past.net/1/1/2005/.

Joussaume, S., Taylor, K. E., Braconnot, P., Mitchell, J. F. B., Kutzbach, J. E., Harrison, S. P., Prentice, I. C., Broccoli, A. J., Abe-Ouchi, A., Bartlein, P. J., Bonfils, C., Dong, B., Guiot, J., Herterich, K., Hewitt, C. D., Jolly, D., Kim, J. W., Kislov, A., Kitoh, A., Loutre, M. F., Masson, V., McAvaney, B., McFarlane, N., de Noblet, N., Peltier, W. R., Peterschmitt, J. Y., Pollard, D., Rind, D., Royer, J. F., Schlesinger, M. E., Syktus, J., Thompson, S., Valdes, P., Vettoretti, G., Webb, R. S., and Wyputta, U.: Monsoon Changes for 6000 Years Ago: Results of 18 Simulations from the Paleoclimate Modeling Intercomparison Project (PMIP), Geophys. Res. Lett., 26, 859-862, 1999.

K-1-Model-Developers, 2004: K-1 Coupled Gcm (Miroc Description)1, 34 pp., 2004.

Kaplan, J. O., Bigelow, N. H., Prentice, C., Harrison, S., Bartlein, P. J., Christensen, T. R., Cramer, W., Matveyeva, N. V., Mc
Guire, A. D., Murray, D., Razzhivin, V. Y., Smith, B., Walker, D. A., Anderson, P. J., Andreev, A., Brubaker, L. B., Edwards, M. E., and Lozhkin, A. V.: Climate Change and Arctic Ecosystems: 2. Modeling, Paleodata-Model Comparisons, and Future Projections, J. Geophys. Res., 108(D19), 8170, doi:10.1029/2002JD002558, 2003.

Khodri, M., Cane, M. A., Kukla, G., Gavin, J., and Braconnot, P.: The Impact of Precession Changes on the Arctic Climate During the Last Interglacial-Glacial Transition, Earth Planet. Sci. Lett., 236, 285-304, 2005.

Kutzbach, J. E. and Liu, Z.: Response of the African Monsoon to Orbital Forcing and Ocean Feedbacks in the Middle Holocene, Science, 278, 440-443, 1997.

Leduc, G., Vidal, L., Tachikawa, K., Rostek, F., Sonzogni, C., Beaufort, L., and Bard, E.: Moisture Transport across Central America as a Positive Feedback on Abrupt Climatic Changes, Nature, 445, 908-911, 2007.

Levis, S., Bonan, G. B., and Bonfils, C.: Soil Feedback Drives the Mid-Holocene North African Monsoon Northward in Fully Coupled CCSM2 Simulations with a Dynamic Vegetation Model, Clim. Dyn., 23, 791-802, 2004.

Liu, Z., Harrison, S. P., Kutzbach, J., and Otto-Bliesner, B.: Global Monsoons in the Mid-Holocene and Oceanic Feedback, Clim. Dyn., 22, 157-182, 2004.

Manabe, S. and Broccoli, A. J.: A Comparison of Climate Model Sensitivity with Data from the Last Glacial Maximum, J. Atmos. Sci., 42, 2643-2651, 1985.

Marsland, S. J., Haak, H., Jungclaus, J. H., Latif, M., and Roske, F.: The Max-Planck-Institute Global Ocean/Sea Ice Model with Orthogonal Curvilinear Coordinates, Ocean Model., 5, 91-127, 2003.

Marti, O., Braconnot, P., Bellier, J., Benshila, R., Bony, S., Brockmann, P., Cadule, P., Caubel, A., Denvil, S., Dufresne, J. L., Fairhead, L., Filiberti, M. A., Foujols, M.-A., Fichefet, T., Friedlingstein, P., Goosse, H., Grandpeix, J. Y., Hourdin, F., Krinner, G., Lévy, C., Madec, G., Musat, I., deNoblet, N., Polcher, J., and Talandier, C.: The New IPSL Climate System Model: IPSL-Cm4, Note du Pôle de Modélisation, n. 26, ISSN 1288-1619, 2005.

Masson-Delmotte, V., Kageyama, M., Braconnot, P., Charbit, S., Krinner, G., Ritz, C., Guilyardi, E., Jouzel, J., Abe-Ouchi, A., Crucifix, M., Gladstone, R., Hewitt, C., Kitoh, A., LeGrande, A., Marti, O., Merkel, U., Motoi, T., Ohgaito, R., Otto-Bliesner, B., Peltier, W., Ross, I., Valdes, P., Vettoretti, G., Weber, S., Wolk, F., and Yu, Y.: Past and Future Polar Amplification of Climate Change: Climate Model Intercomparisons and Ice-Core Constraints, Clim. Dyn., 26, 513-529, 2006.

Meehl, G. A., Washington, W. M., Arblaster, J. M., and Hu, A. X.: Factors Affecting Climate Sensitivity in Global Coupled Models, J. Climate, 17, 1584-1596, 2004.

Otto-Bliesner, B. L., Brady, E. C., Clauzet, G., Tomas, R., Levis, S., and Kothavala, Z.: Last Glacial Maximum and Holocene Climate in Ccsm3, J. Climate, 19, 2526-2544, 2006.

Renssen, H., Goosse, H., Fichefet, T., Brovkin, V., Driesschaert, E., and Wolk, F.: Simulating the Holocene Climate Evolution at Northern High Latitudes Using a Coupled Atmosphere-Sea IceOcean-Vegetation Model, Clim. Dyn., 24, 23-43, 2005.

Roeckner, E., Bauml, G., Bonaventura, L., Brokopf, R., Esch, M., Giorgetta, M., Hagemann, S., Kirchner, I., Kornblueh, L., Manzini, E., Rhodin, A., Schlese, U., Schulzweida, U., and 
Tompkins, A.: The Atmospheric General Circulation Model Echam5, Part I: Model Description, internal report 349, 144 pp., 2003.

Schneider von Deimling, T., Ganopolski, A., Held, H., and Rahmstorf, S.: How Cold Was the Last Glacial Maximum?, Geophys. Res. Lett., 33, L14709, doi:10.1029/2006GL026484, 2006a.

Schneider von Deimling, T., Held, H., Ganopolski, A., and Rahmstorf, S.: Climate Sensitivity Estimated from Ensemble Simulations of Glacial Climate, Clim. Dyn., 27, 149-163, 2006b.

Shin, S. I., Liu, Z., Otto-Bliesner, B., Brady, E. C., Kutzbach, J. E., and Harrison, S. P.: A Simulation of the Last Glacial Maximum Climate Using the NCAR-CCSM, Clim. Dyn., 20, 127151, 2003.

Street Perrott, F. A., Mitchell, J., Marchand, D. S., and Brunner, J. S.: Milankovitch and Albedo Forcing on the Tropical Monsoons: A Comparison of Geological Evidence and Numerical Simulations for 9000 Yr BP, Transactions of the Royal Society of Edinburgh, 81, 407-427, 1990.

$\mathrm{Su}, \mathrm{H}$. and Neelin, J. D.: Dynamical Mechanisms for African Monsoon Changes During the Mid-Holocene, J. Geophys. Res.Atmos., 110, D19105, doi:10.1029/2005JD005806, 2005.

Taylor, K. E., Hewitt, C., Braconnot, P., Broccoli, A. J., Doutriaux, C., Mitchell, J. F. B., and groups, P. p.: Analysis of Forcing, Response, and Feedbacks in a Paleoclimate Modeling Experiment, Paleoclimate Modeling Intercomparison Project (PMIP), Proceedings of the thrid PMIP Workshop, La Huardière, Canada, 271, 2000.

Taylor, K. E., Crucifix, M., Braconnot, P., Hewitt, C., Doutriaux, C., Webb, M. J., Broccoli, A. J., and Mitchell, J. F. B.: Estimating Shortwave Radiative Forcing and Response in Climate Models, J. Climate, in press, 2007.

Texier, D., de Noblet, N., Harrison, S. P., Haxeltine, A., Jolly, D., Joussaume, S., Laarif, F., Prentice, I. C., and Tarasov, P.: Quantifying the Role of Biosphere-Atmosphere Feedbacks in Climate Change: Coupled Model Simulations for 6000 Years BP and Comparison with Palaeodata for Northern Eurasia and Northern Africa, Clim. Dyn., 13, 865-882, 1997.
Vries, P. and Weber, S. L.: The Atlantic Freshwater Budget as a Diagnostic for the Existence of a Stable Shut-Down of the Meridional Overturning Circulation, Geophys. Res. Lett., 32, L09606, doi:10.1029/2004GL021450, 2005.

Wohlfahrt, J., Harrison, S. P., and Braconnot, P.: Synergistic Feedbacks between Ocean and Vegetation on Mid- and High-Latitude Climates During the Mid-Holocene, Clim. Dyn., 22, 223-238, 2004.

Xie, P. and Arkin, P.: Analyses of Global Monthly Precipitation Using Gauge Observations, Satellite Estimates, and Numerical Model Predictions, J. Climate, 9, 840-858, 1996.

Yu, Y. Q., Yu, R. C., Zhang, X. H., and Liu, H. L.: A Flexible Coupled Ocean-Atmosphere General Circulation Model, Adv. Atmos. Sci., 19, 169-190, 2002.

Yu, Y. Q., Zhang, X. H., and Guo, Y. F.: Global Coupled OceanAtmosphere General Circulation Models in Lasg/Iap, Adv. Atmos. Sci., 21, 444-455, 2004.

Yukimoto, S., Noda, A., Kitoh, A., Hosaka, M., Yoshimura, H., Uchiyama, T., Shibata, K., Arakawa, O., and Kusunoki, S.: Present-Day Climate and Climate Sensitivity in the Meteorological Research Institute Coupled Gcm Version 2.3 (Mri-Cgcm2.3), J. Meteorol. Soc. Japan, 84, 333-363, 2006.

Zhang, R. and Delworth, T. L.: Simulated Tropical Response to a Substantial Weakening of the Atlantic Thermohaline Circulation, J. Climate, 18, 1853-1860, 2005.

Zhao, Y., Braconnot, P., Marti, O., Harrison, S. P., Hewitt, C., Kitoh, A., Liu, Z., Mikolajewicz, U., Otto-Bliesner, B., and Weber, S. L.: A Multi-Model Analysis of the Role of the Ocean on the African and Indian Monsoon During the Mid-Holocene, Clim. Dyn., 25, 777-800, 2005.

Zhao, Y., Braconnot, P., Harrison, S. P., Yiou, P., and Marti, O.: Simulated Changes in the Relationship between Tropical Ocean Temperatures and the Western African Monsoon During the MidHolocene, Clim. Dyn., 28, 533-551, 2007. 